\title{
Ethnic Identity and Personal Well-being of People of Color: A Meta-Analysis
}

Timothy B. Smith

Brigham Young University, tbs@byu.edu

Lynda Silva

Follow this and additional works at: https://scholarsarchive.byu.edu/facpub

Part of the Counseling Psychology Commons, and the Special Education and Teaching Commons

\section{Original Publication Citation}

Smith, T. B., \& Sylva, L. (211). Ethnic identity and personal well-being of people of color: A metaanalysis. Journal of Counseling Psychology, 58, 42-6. http://www.apa.org/pubs/journals/cou/ index.aspx

\section{BYU ScholarsArchive Citation}

Smith, Timothy B. and Silva, Lynda, "Ethnic Identity and Personal Well-being of People of Color: A MetaAnalysis" (2011). Faculty Publications. 88.

https://scholarsarchive.byu.edu/facpub/88

This Peer-Reviewed Article is brought to you for free and open access by BYU ScholarsArchive. It has been accepted for inclusion in Faculty Publications by an authorized administrator of BYU ScholarsArchive. For more information, please contact ellen_amatangelo@byu.edu. 


\author{
Ethnic Identity and Personal Well-being \\ of People of Color: A Meta-analysis
}

Timothy B. Smith

Lynda Silva

Brigham Young University

Smith, T. B., \& Sylva, L. (2011). Ethnic identity and personal well-being of people of color: A meta-analysis. Journal of Counseling Psychology, 58, 42-60.

Correspondence concerning this manuscript may be addressed to Timothy B. Smith, Department of Counseling Psychology and Special Education, 340 MCKB, Brigham Young University, Provo, UT 84602; email: tbs@byu.edu. 


\begin{abstract}
This meta-analysis summarized research examining the relationship between the constructs of ethnic identity and personal well-being among people of color in North America. Data from 184 studies analyzed using random effects models yielded an omnibus effect size of $r=.17$, suggesting a modest relationship between the two constructs. The relationship was somewhat stronger among adolescents and young adults than among adults over age 40. No differences were observed across participant race, gender, or socioeconomic status, which findings support the general relevance of ethnic identity across people of color. Studies correlating ethnic identity with self-esteem and positive well-being yielded average effect sizes twice as large as those from studies correlating ethnic identity with personal distress or mental health symptoms. Thus ethnic identity was more strongly related to positive well-being than to compromised well-being.

Overall, the corpus of research located in this review consisted of correlational designs; limited scholarship has addressed causal mechanisms, mediating factors, or psychological functions of ethnic identity across different social contexts.
\end{abstract}

Keywords: ethnic identity, mental health, well-being, meta-analysis 


\section{Ethnic Identity and Personal Well-being of People of Color: A Meta-analysis}

Identity formation has long been considered a crucial aspect of individuals' development and psychological well-being (Erikson, 1959/1980; May \& Yalom, 2005; Rogers, 1961).

Historically much of the psychological literature focused on idiosyncratic characteristics that differentiate oneself from other individuals (Erikson, 1959/1980), but in recent years scholars have considered collective/social aspects of identity (Adams \& Marshall, 1996; Amiot, de la Sablonnière, Terry, \& Smith, 2007; Berman, Schwartz, Kurtines, \& Berman, 2001; Berzonsky, 1989; Grotevant, 1987). In particular, the construct of ethnic identity has received sustained attention (Atkinson, Morten \& Sue, 1998; Ong, Phinney, \& Dennis, 2006; Phinney, 1989, 2000; Ruiz, 1990), including a recent special section of the Journal of Counseling Psychology (Ponterotto \& Mallinckrodt, 2007).

Ethnic identity is the degree to which individuals perceive themselves included and aligned with an ethnic group. Ethnic identity "is a central defining characteristic of many individuals, particularly those who are members of minority ... groups" (Phinney, 2000, p. 256). The psychological importance of ethnic identity among ethnic minority groups can be attributed to discrimination and differentiation experienced by these groups (Tajfel \& Turner, 1986). In the face of opposition and marginalization, a strong ethnic identity helps individuals recognize positive virtues about their own ethnic group, minimizing effects of denigrating beliefs perpetuated in society (e.g., Outten, Schmitt, Garcia, \& Branscombe, 2009; Ruiz, 1990). More than a mere cognitive heuristic or coping strategy, ethnic identity pervades both worldview and behavior; it is a complex construct articulated as "a process of exploring the implications of one's ethnicity and coming to understand and affirm one's membership in an ethnic group" (Ong et al., 
2006, p. 963). Descriptions of ethnic identity include elements such as ethnic self-identification; affective components such as a sense of belonging, pride, and affirmation; cognitive components such as knowledge of history and traditions; value orientations such as individualism or collectivism; and differences in components of ethnic identity related to age, phenotype, and context (Phinney, 2000).

\section{Theoretical Conceptualizations of Ethnic Identity}

Ethnic identity has been conceptualized differently by different scholars (e.g., Cross \& Cross, 2008; Trimble, 2007). Most researchers have based their conceptualizations on the tenets of social identity theory (Tajfel \& Turner, 1986) and Erik Erikson's model of ego identity development, which had suggested that one's personal identity includes "a persistent sharing of some kind of essential character with others" (1959/1980, p.101). In this same tradition, the elaboration of Erikson's model by Marcia and colleagues (1993) has been used to identify different ethnic identity statuses, characterized by the presence or absence of exploration and commitment (Phinney, 1989; Umaña-Taylor, Yazedjian, \& Bamaca-Gomez, 2004).

Conceptualizations based on these theoretical underpinnings have generally been associated with the work of Jean Phinney (1990), although subsequent refinement has been provided by many others.

An alternative conceptualization of ethnic identity has been provided by Bill Cross, whose groundbreaking description of self-identification among African Americans (1971) was informed by the writings of W. E. B. Du Bois (1903) and, more particularly, Franz Fanon $(1963 ; 1967)$. This line of scholarship considers dynamics associated with inter-group oppression, marginalization, and internalized racism. Cross has recently developed a holistic model of racial, ethnic, and cultural identity (Cross \& Cross, 2008), but his early work proved most influential to 
the construct of racial identity (Helms, 1984), which has become distinct from ethnic identity in the psychological literature. Because the distinction between racial identity and ethnic identity is not intuitive, it warrants attention here.

In the Encyclopedia of Psychology, the term racial identity refers to the unique experience of a specific racial group, such as African American, while ethnic identity characterizes one's sense of self in broader terms including culture, race, language, or kinship (Burlew, 2000). Models of racial identity tend to be specific to a particular race (i.e., Cross, 1971; Helms, 1990), but the principle of ethnic identity applies across multiple racial and ethnic groups (Phinney, 1989, 1996). Moreover, descriptions of racial identity explicitly account for intergroup relations, social structures, and internalized stereotypes (Helms, 1990), whereas ethnic identity models do not emphasize those considerations over others (Phinney, 1996). Ethnic identity focuses on the notion of self-identification, whereas racial identity incorporates the influence of societal oppression illuminated through the paradigm of anti-racism (e.g., Helms, 1990; Helms \& Talleyrand, 1997). In sum, "racial and ethnic identities differ widely in the ways that they have been defined and studied...the literature dealing with these two types of identity is quite divergent" (Phinney \& Ong, 2007, p. 274).

Against the prevailing practice to distinguish ethnic identity from racial identity Bill Cross has cogently argued that "racial, ethnic, and cultural identity overlap at the level of lived experience to the point that there is little reason to associate each construct with a distinct identity constellation" (Cross \& Cross, 2008, p. 156). Notwithstanding this rationale, confusion and disorder have resulted when researchers have used these terms interchangeably (Trimble, 2007). The terms are overlapping but not synonymous (Phinney \& Ong, 2007). Because conceptual blurring has occurred between ethnic identity and racial identity, it is essential that researchers 
clarify their intended focus (Helms, 2007). "If race and ethnicity should be treated as separate yet related constructs, so too should racial identity and ethnic identity" (Cokely, 2007, p. 518).

Given the differences in how researchers have conceptualized racial identity and ethnic identity, it is not surprising that the measures commonly used to quantify the two constructs do not share a compatible dimension. Statistical aggregation across measures of racial identity and ethnic identity would therefore be inappropriate. Moreover, subscales of commonly used measures of racial identity cannot be meaningfully combined to yield an overall score (Helms, 1990). Thus the present study follows recommendations to specify the variables involved (Ponterotto \& Park-Taylor, 2007) and restricts its focus to the construct of ethnic identity.

\section{Association of Ethnic Identity with Well-being}

The psychology literature affirms ethnic identity as a positive personal disposition; accurate self-evaluation should optimally incorporate one's ethnic heritage. Similar to the achievement of a strong ego identity (Marcia et al., 1993), a strong ethnic identity that is based on sufficient exploration and experience should provide a foundation of self-knowledge from which life decisions can be made with confidence. Identification with a larger collective can also provide a sense of belonging and social support. Thus ethnic identity can provide a sense of strength, competence, and self-acceptance when negotiating complex environmental contingencies (e.g., Outten et al., 2009; Ruiz, 1990). By definition, high levels of ethnic identity should be positively associated with personal well-being.

Numerous research studies have found a positive relationship between a strong ethnic identity and indicators of self-esteem and personal adjustment. For example, a large study $(N=$ 5,423 ) of young adolescents documented significant positive correlations between ethnic identity and a variety of positive attributes such as coping ability, mastery, self-esteem, and optimism 
(Roberts et al., 1999). Overall research findings appear to consistently point to the positive association between ethnic identity and multiple aspects of personal well-being across ethnic groups (e.g., Phinney, Cantu, \& Kurtz, 1997). Many in the field have interpreted these consistent correlations to indicate causal mediation, with positive ethnic identity assumed to buffer against distress experienced by ethnic minority groups (e.g., Ponterotto \& Park-Taylor, 2007).

Although the buffering role of ethnic identity against distress has been widely cited in the literature, a few scholars have observed that in some cases stronger ethnic identity may actually exacerbate susceptibility to distress (e.g., Yip, Gee, \& Takeuchi, 2008; Yoo \& Lee, 2008). According to self-categorization theory (Turner, Hogg, Oakes, Reicher, \& Wetherell, 1987), individuals attune to environmental cues relevant to their own identity. Research has confirmed that individuals with strong ethnic identity attend to inter-ethnic dynamics (Syed \& Azmitia, 2008; 2010) and are more likely to report experiences of discrimination (e.g., Sellers \& Shelton, 2003) and experience distress because of discrimination (McCoy \& Major, 2003). Threat to a group with which one identifies strongly can be experienced as a threat to the self. Hence, the present emphasis in the literature on the positive buffering role of ethnic identity against distress should be tempered with the recognition that strong ethnic identity may exacerbate distress among individuals who experience ethnic discrimination.

\section{Contextual Factors Relevant to the Association between Ethnic Identity and Well-being}

Although the construct of ethnic identity should generalize across populations (Phinney, $1989 ; 2000)$, recent scholarship has increasingly sought to delineate the circumstances under which ethnic identity is most salient to well-being. The most consistent delineation has involved ethnicity itself. The research literature has largely focused on the experiences of people of color, rather than Whites, for several reasons. Studies have consistently documented that Whites in 
North America tend to feel more ambivalent about their ethnic identity than people of color, for whom ethnic identification is more salient (e.g., Bracey, Bamaca, \& Umaña-Taylor, 2004; Phinney, 1990).

The view of ethnic identity as the link between ethnicity and psychological outcomes is based on the assumption that ethnicity is a meaningful psychological variable to the extent that it has salience and centrality for the individuals involved. For most Americans of European background, ethnicity is not a salient or important part of their identity, and they can choose what role, if any, it will have for them (Phinney, 1996, p. 922).

Presumably because of this lower valuation of ethnic identity, the positive correlation observed between ethnic identity and well-being in people of color does not occur with consistency among White populations (e.g., Carter et al., 2005). Moreover, because of social dynamics relevant to majority vs. minority status (Tajfel \& Turner, 1986), there are reasons to suspect that ethnic identity may serve different psychological functions for White people compared to other groups in North America. Both the subjective experience of ethnic identity and the factors that likely mediate its association with well-being may differ between Whites and people of color. For instance, many researchers have been interested in how ethnic identity may buffer against ethnic prejudice (e.g., McCoy \& Major, 2003), which meditational pathway would be much less relevant for Whites than for historically oppressed groups in North America. Based on these several considerations, we delimited our focus in this manuscript to the experiences of people of color, with the understanding that specifying target populations is appropriate and even desirable in psychological research (Sue, 1999).

Recent scholarship has also examined other contextual factors besides ethnicity that may moderate the association between well-being and ethnic identity, including age, gender, level of acculturation, and socioeconomic status, each highlighted briefly here. Given the relevance of identity development processes for adolescents and young adults (Erikson, 1959/1980), most of 
the research on ethnic identity has focused on the experiences of high school students (e.g., Fuligni, Witkow, \& Garcia, 2005) and college students (e.g., Ong et al., 2006). Although research generally supports the developmental significance of ethnic identity for adolescents and young adults, other age groups have been investigated infrequently (Tsai, Chentsova-Dutton, \& Wong, 2002). With respect to the possible influence of gender, studies investigating gender identity have concluded that it is positively associated with ethnic identity (e.g., Hoffman, 2006) and that ethnic identity development may differ across males and females (Hughes, Hagelskamp, Way, \& Foust, 2009). However, data contrasted across gender yield either minimal differences or mixed findings (e.g., Phinney \& Alipuria, 1990; Phinney et al., 1997; Tatman, 1996). Other studies have found that acculturation to Western society is associated with both ethnic identity and well-being for immigrants and refugees in North America (Barry, 2000; Tsai et al., 2002). Similarly, socioeconomic status has been found to be associated with both ethnic identity and well-being, with stressors associated with ethnic discrimination being compounded by poverty (Myers, 2009). Thus the relevance of ethnic identity to well-being appears to be moderated by personal and social characteristics. Scholars should therefore attend to contextual factors when studying ethnic identity (Syed \& Azmitia, 2008; 2010).

\section{Need for Synthesis of Existing Research}

Scholars have consistently concluded that a strong ethnic identity is positively associated with personal well-being and successful life adjustment for people of color (e.g., Ong et al., 2006; Phinney, 1989; Phinney et al., 1997; Roberts et al., 1999). However, the overall magnitude of the association between ethnic identity and well-being has remained uncertain, and the impact of possible moderating variables has been unclear (Fuligni et al., 2005; Ong et al., 2006; Phinney, 1990; Phinney et al., 1997). Large numbers of manuscripts on the topic have appeared during the 
past two decades, with the body of research examining the relationship between ethnic identity and well-being growing exponentially. The literature has been described as unwieldy and in need of synthesis (Ponterotto \& Mallinckrodt, 2007). A synthesis of this research would help to clarify current findings and guide future research efforts. We therefore undertook a systematic review of the research to ascertain the overall magnitude of the association between ethnic identity and well-being and to determine if that association may be moderated by study and participant characteristics.

\section{Method}

Published and unpublished studies examining the relationship between ethnic identity of people of color and one or more aspects of their personal well-being were included in this metaanalysis. Basic criteria for inclusion were that the study was written in English and that it provided quantitative data regarding this relationship for individuals identifying themselves as African American, Asian American, Hispanic/Latino(a) American, Native American, and/or Pacific Islander American. When studies also involved White participants, we analyzed only the disaggregated data for the groups just listed. Included studies had a quantitative measure of ethnic identity (explicitly using the term ethnic or ethnicity) that was statistically associated with at least one quantitative measure of an aspect of personal well-being (e.g., self-esteem, coping ability, symptoms of depression). Studies frequently reported data on other variables (e.g., gender identity), but only data specific to the two constructs of ethnic identity and well-being were extracted. We recognized that wording and conceptual differences would occur across distinct scales measuring these two global constructs, so our initial analyses that combined measures of ethnic identity and well-being were followed by analyses disaggregating the different 
measures used across studies. All quantitative research designs except single-case studies were eligible for inclusion. Studies of populations outside the U.S. or Canada were excluded.

Three strategies helped to identify suitable published and unpublished studies. First, research team members searched abstracts retrieved from the following electronic databases: PsychINFO, PsycArticles, Science Citation Index (SCI), Social Sciences Abstracts, Social Sciences Citation Index (SSCI), and Digital Dissertations. In these searches, the phrase ethnic identity(ies) was crossed with a list of dozens of descriptors of well-being, including mental health, self-esteem, happiness, depression, etc. Second, the reference sections of identified studies were reviewed in order to locate additional articles that fit the inclusion criteria but were not initially found through the database searches. Third, attempts were made to contact authors who had published two or more articles on this topic, asking for information regarding other (unpublished) studies that could possibly be included in the meta-analysis.

\section{Data Coding}

Variables coded across all studies included (a) the source of the study (journal article, dissertation, etc.); (b) the number of participants and their age, education, gender, race, and socioeconomic status; (c) the location of data collection if reported (public school, clinical setting, etc.); (d) the research design; and (e) the measures of ethnic identity and well-being used in the study. Four graduate and six undergraduate students were trained in meta-analytic coding, and these team members coded manuscripts in pairs to enhance the accuracy of coding decisions and data entry. Each article was coded by two separate pairs of coders. The inter-rater agreement of coding decisions across coding pairs was acceptably high for categorical variables (average Cohen's Kappa $=.86$ ) and for continuous variables (average intraclass correlation coefficient $=$ .93 utilizing one-way random effects models for single measures). Inter-rater agreement was high 
because (1) coders had worked together on similar projects previously, and (2) the majority of information obtained from the studies was extracted verbatim from the documents, which reduced the likelihood of coding error. When a manuscript did not contain certain information, the study was excluded from the analysis of that particular variable but not from other analyses. When coding inconsistencies occurred across the teams, the disparities were resolved through further examination of the manuscript.

\section{Computation and Analysis of Effect Size Estimates}

The studies included in this meta-analysis frequently (90\%) reported data in terms of bivariate correlations (Pearson's $r$ ). Reports including other statistics (e.g., analyses of variance, $t$-tests, $p$-values) were transformed to the metric of $r$ using statistical software. Coders assigned a positive value to effect sizes indicating a stronger ethnic identity co-occurring with greater wellbeing (or weaker ethnic identity co-occurring with symptoms of mental illness, distress, etc.), with a negative value indicating an inverse association between ethnic identity and personal wellbeing. In two cases when an analysis was reported to be "statistically significant" but no statistic was provided, the $r$ value was determined by the corresponding alpha level (assuming two-tailed $a l p h a=.05$ unless reported otherwise). In six cases analyses described as "non-significant" without any additional information were set to $r=.00$.

Many studies used in the meta-analysis reported data on multiple measures of well-being, such as self-esteem and coping ability. Similarly, some studies reported data on multiple groups (i.e., across races or genders). If each of these data points had been included in the omnibus analysis, the results would be biased in favor of those studies that had contributed multiple effect sizes. Moreover, inclusion of multiple effect sizes within studies would violate the assumption of independent samples; even though the particular sub-samples may have differed on a 
characteristic such as race, the data shared a common method, experimental design, location and setting, etc. To overcome this issue, all effect sizes within each study were averaged (weighted by the number of participants included in each analysis) to compute an aggregate effect size for that particular study (Mullen, 1989). Thus each study contributed only one data point to the calculation of the omnibus effect size. However, in one instance where a grouping variable that was found to moderate the omnibus results required subsequent detailed exploration to better interpret the finding (the type of dependent measure used within studies), we conducted an additional analysis by shifting the unit of analysis (Cooper, 1998). In that analysis, we included multiple effect sizes within studies if they were based on distinct measures of well-being (i.e., self-esteem and symptoms of depression). Thus this approach disaggregated results across conceptually distinct measures used within studies.

Because factors other than ethnic identity influence well-being and because the magnitude of the association between ethnic identity and well-being was expected to differ across individual participants and across individual studies, random effects models were used in analyzing the data using macros for SPSS provided by Lipsey and Wilson (2001). The use of a random effects model also allows for generalization beyond the studies included in the analyses (Hedges \& Vevea, 1998).

\section{Results}

\section{Descriptive Characteristics}

Statistically non-redundant effect sizes were extracted from 184 studies examining the relationship between ethnic identity and one or more aspects of personal well-being (Table 1). The number of participants represented across all studies was 41,626, 62 percent of whom were female, and the average age of participants was 22.9 years. Average ethnic/racial composition of 
participants across all studies was 33\% African Americans, 35\% Asian Americans, 21\% Hispanic/Latino(a) Americans, 5\% Native Americans, 1\% Pacific Islander Americans, 5\% from “other" non-White groups.

\section{Omnibus Analysis}

Across all 184 studies, the random effects weighted average effect size was $r=.173$ (SE $=$ $.01, p<.0001$ ), with a $95 \%$ confidence interval of $r=.15$ to $r=.19$. Effect size estimates ranged from $r=-.18$ to $r=.57$. The effect size estimates demonstrated considerable variability with the index of heterogeneity reaching statistical significance $\left(Q_{(183)}=579.5, p<.0001 ; I^{2}=71.5 \%\right)$. This suggests that the systematic effect size variability was greater than expected from sampling error alone. Additional analyses were conducted in order to determine the degree to which different variables moderated the variability in effect size estimates.

\section{Assessment of Possible Publication Bias}

The publication status of research studies used in a meta-analysis can potentially impact its findings because of the tendency for meta-analyses to include predominantly published studies, which are typically easier to obtain than unpublished studies and which tend to have effect sizes of larger magnitude than unpublished studies. In the present meta-analysis, the average effect size of the published studies was higher $(r=.19)$ than that of the unpublished studies $(r=.16 ; Q=3.1, p=.05)$. However, the number of unpublished studies included in this meta-analysis ( $k=108$, all unpublished doctoral dissertations) actually exceeded the number of published studies $(k=76)$. Analysis of a funnel plot (effect sizes by standard errors) indicated that the data were evenly dispersed with no missing corners, which would have suggested missing studies with small numbers of participants - those least likely to be published (Begg, 1994; Lipsey \& Wilson, 2001). Analyses using Duvall and Tweedie's (2000a, 2000b) “trim and fill” 
method also led us to conclude that publication bias did not adversely impact the results of this meta-analysis.

\section{Moderation by Participant Characteristics}

Because person level factors influence both ethnic identity and well-being, it was essential to ascertain whether the association between those two constructs may have differed as a function of participant characteristics (e.g., age, gender, race). To detect whether or not participant characteristics had any systematic influence on effect size magnitude we conducted random effects weighted correlations and analyses of variance.

Previous scholarship has emphasized the developmental value of ethnic identity to wellbeing (e.g., Phinney, 2006), so we first sought to establish whether the average age of the research samples accounted for a significant portion of the between-studies variance of effect sizes. The resulting correlation of $-.20(p=.007)$ suggested that studies with participants who were younger tended to yield effect sizes of a higher magnitude than those in which participants were older. Inspection of the associated scatterplot indicated that none of the studies with participants averaging at least 40 years of age had effect sizes that were greater than .25 , whereas studies with participants younger than 40 years had effect sizes across a broader range of positive values. When the nine studies with participants averaging 40 years of age or older were temporarily excluded, the correlation between participant age and effect size magnitude was no longer statistically significant $(r=-.07)$.

Because the relevance of ethnic identity to well-being may interact with gender (e.g., Hughes et al., 2009), the possible influence of participant gender was explored by correlating the percentage of females in each study with its effect size. The resulting random effects weighted 
correlation was small $(r=-.12, p=.10)$, indicating that participant gender composition did not moderate the overall results.

Previous research has found racial differences in the absolute magnitude of the association between ethnic identity and well-being among people of color (e.g., Yoo \& Lee, 2008), so we compared the results of studies of African Americans, Asian Americans, Hispanic/Latino(a) Americans, and Native Americans (Table 2). The magnitude of the averaged correlations was similar across studies of these distinct groups, indicating no consistent differences $(Q=4.5, p=$ $.21)$.

Both ethnic identity and well-being are associated with acculturation processes (Berry, 2003). In the present meta-analysis, coders sought information regarding participants' level of acculturation but when not directly reported they evaluated several indicators of acculturation: immigration status of the participants (i.e., years/generations of residence in North America), English language proficiency and language spoken at home, level of education, location of residence (i.e., urban ethnic enclave, American Indian reservation), and data collection procedures (i.e., targeting populations likely to be low in acculturation). Studies that contained at least three indicators of low acculturation were coded as having participants with low levels of acculturation; studies describing one to two indicators of low acculturation were coded as having participants with moderate levels of acculturation; studies with at least two indicators of high acculturation were coded as having participants with high levels of acculturation; and studies failing to report pertinent information were not coded with respect to this variable. Analysis of the resulting data indicated that participants' level of acculturation did moderate the results $(Q=10.8$, $p=.01)$. Studies using participants with low levels of acculturation to Western society had 
average effect sizes of smaller magnitude compared to those using participants with moderate and high levels of acculturation.

Because poverty may exacerbate stressors experienced by people of color (Myers, 2009), it was important to investigate whether socioeconomic status moderated the association between ethnic identity and well-being. Analyses with two variables highly associated with socioeconomic status, level of education and participants identified as at-risk for social problems (i.e., delinquency, criminal activity), were also conducted. However, no differences were observed across participant socioeconomic status $(Q=1.6, p=.46)$, level of education $(Q=0.6, p$ $=.74)$, or at-risk status $(Q=3.5, p=.17)$, indicating that the relationship between ethnic identity and well-being did not vary across those conditions.

\section{Moderation by Study Characteristics}

As expected based on previous observations (Ponterotto \& Park-Taylor, 2007), the vast majority of studies used the Multigroup Ethnic Identity Measure (MEIM; Phinney, 1992) to measure ethnic identity (Table 2). However, the magnitude of the overall results remained consistent across studies using different measures of ethnic identity $(Q=1.0, p=.62)$.

Insufficient data were available to conduct more refined analyses contrasting specific measures of ethnic identity. The MEIM was the only measure of ethnic identity used in more than six studies.

Because well-being is necessarily multi-faceted, we investigated differences in the results of studies evaluating distinct components of well-being. The type of dependent variable used within studies did significantly moderate the results $(Q=48.8, p<.0001)$. Participants' ethnic identity was clearly related to their scores on positive aspects of well-being, such as self-esteem. However, participants' ethnic identity was minimally related to their scores on measures of mental health symptoms. Because this finding was noteworthy, we subsequently disaggregated 
the data of studies using more than one type of measurement, such that effect sizes for each measurement type were included in the analysis (shifting units of analysis, as described previously; see Cooper, 1998). The resulting comparison across measurement type also reached statistical significance $(Q=232.9, p<.0001)$. Measures of self-esteem, self-mastery, and general well-being yielded the largest average effect sizes, and measures of mental health symptoms yielded the smallest average effect sizes.

Recognizing that the type of research design used by researchers may yield differences in effect size estimates, we evaluated whether the magnitude of effect sizes obtained in crosssectional studies differed from those of longitudinal studies. Cross-sectional research yielded larger average effect sizes than longitudinal designs $(Q=3.9, p=.05)$.

\section{Regression Model Predicting Effect Sizes from Moderator Variables}

To determine the degree of redundancy among the several statistically significant predictors of effect size magnitude identified in the analyses reported above, we performed a random intercept, fixed slopes multiple regression model. Specifically, effect sizes were regressed on participants' mean age and level of acculturation, design type (cross-sectional vs.

longitudinal), and the type of well-being measured. Values were centered on the between-study means. Thus a value of zero, for example, for mean age, actually represented the typical mean age across the population of studies included in the meta-analysis. To include all cases in the analysis, estimated levels of participant acculturation were contrasted with studies not reporting that information; categories of measures of well-being were similarly dummy coded to contrast with multidimensional measures.

The set of moderator variables accounted for $24 \%$ of the variance in effect sizes, which result was statistically significant $\left(Q_{8}=56.3, p<.0001\right)$; between-studies variance was accounted 
for $\left(Q_{165}=179.1, p=.21\right)$. Table 3 shows the regression coefficients and associated levels of statistical significance for each variable. The parameter labeled "Constant" is the effect size $(r=$ $.172, \mathrm{p}<.0001)$ that would be expected in a study in which all moderator variables took the value of zero. Interpretation of the B weights reveals the extent to which each study characteristic would be expected to influence the observed overall effect size when controlling for the presence of the other variables. Thus when studies use measures of mental health the expected effect size would be $r=.079$ (.172 less the B weight of -.093), when studies use measures of self-esteem the expected effect size would be $r=.247(.172+.075)$, and when studies use measures of wellbeing the expected effect size would be $r=.252(.172+.08)$. In the presence of the other variables, study design (cross-sectional vs. longitudinal) no longer predicted effect size magnitude, and low levels of participant acculturation (but not medium or high levels) explained differences in effect size magnitude.

\section{Discussion}

This meta-analysis synthesized contemporary research examining the relationship between the construct of ethnic identity (the degree to which individuals perceive themselves included and aligned with an ethnic group) and personal well-being among people of color residing in North America. The overall findings demonstrated a modest positive relationship between the two constructs $(r=.17)$. This result is consistent with previous conclusions that although ethnic identity is consistently positively related to measures of well-being, it accounts for a small proportion of variance (Phinney, 1992; Phinney \& Alipuria, 1990; Phinney et al., 1997; Roberts et al., 1999). Even after considering possible qualifications of the statistics (e.g., Ozer, 1985), 97\% of the variance remains unexplained (coefficient of non-determination). Ethnic 
identity may be highly salient for many people of color, but many other factors influence their well-being.

Several contributions of the present meta-analysis came to light from the analyses of possible moderating variables. First, the association between ethnic identity and well-being did not differ as a function of several participant characteristics: race, gender, education level, and socioeconomic status. The association of ethnic identity with well-being remains consistent but modest across those conditions.

Second, because the vast majority of research studies in the field (and 69\% of the studies in this meta-analysis) measured ethnic identity with the MEIM (Phinney, 1992), it was essential to confirm that the results of studies using that instrument were similar to those of studies using other measures. The data supported that conclusion: The results obtained with the MEIM did not differ from those obtained with other instruments. The results of this meta-analysis may therefore represent the broad construct of ethnic identity, not merely the MEIM's operationalization of that construct.

Third, studies with younger participants tended to have average effect sizes of slightly greater magnitude than studies with participants over the age of 40 years. This finding could indicate that a strong ethnic identity benefits adolescents and young adults more than older adults (e.g., Yip et al., 2008). Middle-aged and older adults may base their well-being on factors besides ethnic identity, or their ethnic identity may be better established, such that it is taken for granted in the broad context of well-being. Although Erikson (1959/1980) and other identity theorists (Berzonsky, 1989; Grotevant, 1987) emphasize that identity formation is a lifelong process, it is nonetheless most critical for adolescents and young adults (Berman et al., 2001; Erikson, 1959/1980; Marcia et al., 1993). Nevertheless, because relatively few studies examined 
middle-aged and older adults, the lower magnitude of the results observed in this meta-analysis among research participants over 40 years of age will require subsequent confirmation through future studies of those populations (Tsai et al., 2002).

Fourth, the level of participant acculturation moderated the results of the meta-analysis. The relationship between ethnic identity and well-being was minimal in five studies with participants for whom there was strong evidence of low acculturation to Western society (i.e., recent immigrants/refugees). Because individuals with low levels of acculturation tend to have ethnically homogeneous social networks (Phinney, Horenczyk, Liebkind, \& Vedder, 2001) their ethnic identity may be taken for granted and remain a psychologically passive construct, despite high absolute levels of in-group identification (Phinney, 2006). Social identity theory (Tajfel \& Turner, 1986) would posit that a group would need to experience contrast (opposition/oppression) for ethnic identity to be activated as a coping strategy, but recent immigrants who reside in ethnic enclaves or, oppositely, who actively seek assimilation (i.e., try to fit in to mainstream society and minimize their differences) may not initially activate ethnic identity as a coping strategy. Nevertheless, theories of acculturation (Berry, 2003) emphasize that multiple processes influence the affirmation of one's own ethnicity and its relevance to well-being, such that an accurate interpretation of our finding would require a more detailed understanding of the participants' contexts than is possible in a meta-analysis. Future research will be needed to clarify the relationship between ethnic identity and well-being as a function of acculturation. In any case, the fact that only five studies investigated low acculturated samples limits confidence in the finding, which could be attributable to sampling error.

Finally, this meta-analysis revealed large differences across the results of studies based on the aspect of well-being evaluated. Ethnic identity was consistently associated with measures of 
self-esteem and well-being, but it was not as strongly related to measures of mental health symptoms, such as depression or anxiety. It is possible that ethnic identity is related to positive personal attributes and perceptions but does not directly buffer against distress or mental illness. It may be that mental health disorders are influenced so strongly by other factors (i.e., coping skills, neurological functioning, socialization) that the contribution of ethnic identity is meager by comparison. Although some have hoped that a strong ethnic identity would protect against psychopathology (Suzuki, Alexander, Lin, \& Duffy, 2006), the data seem to indicate that ethnic identity is largely independent of mental health symptoms and subjective feelings of distress.

\section{Implications for Future Research}

Ethnic identity is a complex concept (Phinney \& Ong, 2007). Hundreds of studies have been conducted on the topic, but this meta-analysis demonstrates that many questions remain regarding the influence of ethnic identity in the lives of people of color. For instance, over many years the consistent positive associations observed between ethnic identity and well-being have led many scholars in the field to assume that a strong ethnic identity contributes to personal wellbeing. While this remains a plausible explanation, we cannot currently provide evidence of causality; all but 2 of the 184 studies in this meta-analysis reported correlational data, but none involved experimental designs. The finding that ethnic identity may not buffer against mental illness, although it has been widely expected to do so, indicates a need for greater clarity regarding its exact influence. For instance, does strength of ethnic identity primarily reflect positive socialization within one's social network and family of origin (Hughes et al, 2008), such that it is actually positive socialization (e.g., close family ties and strong social networks) rather than strength of ethnic identity that is primarily responsible for increased well-being? Future studies that control for socialization factors (i.e., social skills, quality of familial and peer 
relations, institutional/organizational involvement) could begin to isolate the independent contribution of ethnic identity affirmation (e.g., Supple, Ghazarian, Frabutt, Plunkett, \& Sands, 2006).

Much of the research on ethnic identity has already focused on adolescence (Fuligni et al., 2005; Phinney, 1989; Phinney et al., 1997; Roberts et al., 1999). However, as has been pointed out by developmental theorists (e.g., Quintana, 2007), little research has explicitly evaluated relevant developmental processes over time. How does the psychological relevance of ethnic identity change over the lifespan--and for what reasons? Longitudinal studies tracking changes across the lifespan and qualitative research exploring the meaning of ethnic identity for different age cohorts may help to illuminate some of these issues (Phinney \& Ong, 2007; Ponterotto \& Park-Taylor, 2007). Future research can also verify whether the contribution of ethnic identity to well-being differs as a function of individuals' stage of identity development by using direct measures rather than merely using participant age. It would also be useful to simultaneously evaluate conceptually related variables such as (1) ego strength, (2) cognitive complexity, (3) racial forgiveness (Quintana, 2007), and (4) worldview inclusiveness. Understanding which specific components of development mediate the association of ethnic identity with well-being should have direct implications for improving the efficacy of initiatives designed to promote wellbeing.

In addition to exploring changes in ethnic identity over the lifespan, research might profitably involve explicit contrasts between different situations (i.e., low vs. high racial discrimination, low vs. high inter-racial cooperation) in which the psychological functions of ethnic identity may differ. Because ethnic identity may exacerbate the distress of ethnic discrimination (Yoo \& Lee, 2008), it seems essential to give greater research attention to the 
functions of ethnic identity. What motives do individuals' ascribe to their ethnic selfidentification and how do those motives change across settings? Are the functions of ethnic identity conditional upon stable interaction patterns? How do local vs. macro inter-group dynamics influence ethnic identity (Phinney, 2000; Tsai et al., 2002)? Qualitative research studies have documented interactions between ethnic identity and context (e.g., Inman, Howard, Beaumont, \& Walker, 2007), but quantitative research should now more explicitly evaluate differences across settings (e.g., Umaña-Taylor, 2004).

Previous research clearly indicates that ethnic identity is multidimensional (Atkinson, Morten \& Sue, 1998; Phinney \& Ong, 2007; Ruiz, 1990; Umaña-Taylor, 2004). However, the present meta-analysis included data that most often operationalized the construct unidimensionally (i.e., total MEIM scores). Although some evidence questions the underlying assumptions for different theoretical stages/statuses (Quintana, 2007), it would be important for future research to ascertain to what degree the linear relationships with well-being varies across qualitatively different statuses (e.g., exploration, moratorium) and components of identity (e.g., attitudinal, behavioral). "Various components of ethnic identity relate differently to psychological outcomes" (Phinney, 1996, p. 923). Future quantitative research could parse differences in individuals' experiences of ethnic identity that are explicit in only a few contemporary research studies (e.g., Yoo \& Lee, 2008).

One of the most pressing areas for future inquiry concerns the association between ethnic identity and mental health symptoms, including subjective distress. The meta-analytic data showed this association to be of low magnitude. However, the vast majority of studies included in the meta-analysis involved normal members of communities; hence a restriction of range in measures of psychopathology may have artificially attenuated the magnitude of the observed 
correlations. Even though the results of the few studies including at-risk or clinical samples did not differ from those using normal community members, the small number of clinical studies does limit our certainty about the interpretation of the data. Research might productively focus on identifying the situations in which a strong ethnic identity protects against depression and anxiety.

\section{Implications for Practice}

This systematic review of research provides information that can be helpful to psychotherapy and to primary (preventative) interventions. Ethnic identity is frequently a "central defining characteristic" (Phinney, 2000, p. 255) for people of color. Nevertheless, the association of ethnic identity with well-being was found to be highly variable (ranging from $r=$ .18 to $r=.57)$. Rather than assume anything about the relevance of ethnic identity, therapists can explore the clients' perceptions of their well-being and ethnic identity. To minimize possible misinterpretations of their clients' perceptions, therapists can also explore their own ethnic identity and encourage similar exploration among students and supervisees (Ponterotto \& ParkTaylor, 2007).

How clients express their ethnic identity could reflect acquired self-affirmation skills and coping strategies. Knowing these skills and strategies would help a therapist to match interventions to existing client strengths. Alternatively, how individuals manifest their ethnic identity can also reveal circumstantial constraints impacting clients' attitudes and behaviors. Awareness of when clients' ethnicity becomes most salient for them can shed light on important contextual considerations (e.g., Tsai et al., 2002). For example, in what ways does openly affirming one's ethnic identity result in objectification or distress? How does ethnic-specific socialization foster a sense of control in response to a local climate of marginalization? Viewing ethnic identity qualitatively, explicitly accounting for the range of ecological contexts (Neville \& 
Mobley, 2001), should not only help therapists to better understand their clients (Trimble, 2007) but also enhance the therapeutic alliance and improve client outcomes (Atkinson, Bui, \& Mori, 2001). Mental health interventions are most effective when they reflect the specific cultural experiences of the client (Griner \& Smith, 2006; Smith, 2010).

\section{Strengths and Limitations of the Meta-Analysis}

Meta-analysis is a useful method by which a body of empirical research can be evaluated. The aggregation of the results of numerous studies increases the sample size of observations and decreases the standard error of the estimates. Meta-analytic results provide statistical estimates that are less biased than individual studies or narrative literature reviews (Cook \& Leviton, 1982; Cooper, 1998). Meta-analysis also enables the researcher to analyze the impact of specific variables across studies with considerable precision (Lipsey \& Wilson, 2001). In this metaanalysis, 184 studies with a total of 41,626 participants were evaluated, providing greater breadth of coverage than any previous review of the relationship between ethnic identity and well-being.

Of course, meta-analysis has several limitations. First, only studies with quantitative findings can be included (Lipsey \& Wilson, 2001). Case studies and qualitative research that provide indispensible insights on the topic require a separate systematic review. Second, the overall results of the meta-analysis depend on the methodological rigor and the philosophical/theoretical assumptions of the studies included in the meta-analysis (Cooper, 1998; Cooper \& Hedges, 1994; Matt \& Navarro, 1997). Our meta-analytic results have exposed a need for studies that go beyond reporting bi-variate correlations, so future results may differ as methodology becomes more refined. Our results cannot speak to theoretical issues, but the field is currently attending to that arena (Ponterotto \& Park-Taylor, 2007), albeit with a heavy emphasis on measurement rather than clinical considerations. Third, meta-analyses cannot adequately 
control for systematic threats to internal or external validity already present in the literature. For instance, systematic selection of easily accessible participants (i.e., students) could potentially misrepresent the nature of the relationship between ethnic identity and well-being for other populations. Because much of the research reviewed here consisted of unpublished doctoral dissertations, other systematic sources of bias may be present (i.e., inadequate conceptualization or inconsistent procedures). A fourth limitation of meta-analysis is that it is essentially descriptive; causal relationships cannot be demonstrated. For instance, our analyses did not address whether ethnic identity buffers against ethnic discrimination. Future comparative, multilevel, and intervention studies can refine interpretation of the specific psychological functions of ethnic identity.

\section{Conclusion}

Over the past two decades the construct of ethnic identity has received sustained attention in the psychological research literature. The aggregate results of 184 studies conclusively demonstrate that ethnic identity is modestly salient to the self-esteem and well-being of people of color. Nevertheless, (1) the magnitude of the association is highly variable, and (2) positive ethnic identity does not appear to diminish personal distress or reduce symptoms of psychopathology at the aggregate level. This latter finding may be due to increased susceptibility to distress under conditions of ethnic discrimination (Yip et al., 2008; Yoo \& Lee, 2008), but a larger perspective is that mental illness is influenced by multiple factors, of which strength of ethnic self-identification is only one.

In any event, the findings of this review raise questions about possible multiple paths of causal influence. For instance, does ethnic identity enhance self-esteem, or do people of color with high self-esteem value their ethnicity? Until now the field has focused primarily on ethnic 
identity itself, without detailed consideration of how related factors that facilitate well-being (i.e., ego strength, social skills, strength of interpersonal networks, family cohesion, community/organizational involvement) may simultaneously promote ethnic identity development. Studies of this nature may shed additional light on causal considerations, as well as optimal forms of mental health intervention more deeply congruent with client ethnic identity (Trimble, 2007). We anticipate research that addresses these considerations to better promote well-being and mental health among historically oppressed peoples. 


\section{References}

Citations marked with an asterisk were included in the meta-analysis.

*Adams, J. L. (1997). Multiracial identity development: Developmental correlates and themes among multiracial adults. Unpublished doctoral dissertation, Ohio State University, Columbus, $\mathrm{OH}$.

Adams, G. R., \& Marshall, S. (1996). A developmental social psychology of identity: Understanding the person in context. Journal of Adolescence, 19, 429-442. doi:10.1006/jado.1996.0041

*Adelabu, D. H. (2008). Future time perspective, hope, and ethnic identity among African American adolescents. Urban Education, 43(3), 347-360.

doi:10.1177/0042085907311806

*Ali, M. (2006). Impact of acculturation, ethnic identity, religiosity, and individual difference variables on the subjective well-being of Pakistani Muslims in the United States. Unpublished doctoral dissertation, Southern Illinois University, Carbondale, IL.

Amiot, C., de la Sablonnière, R., Terry, D., \& Smith, J. (2007). Integration of social identities in the self: Toward a cognitive-developmental model. Personality and Social Psychology Review, 11(4), 364-388. doi:10.1177/1088868307304091

Atkinson, D. R., Bui, U., \& Mori, S. (2001). Multiculturally sensitive empirically supported treatments: An oxymoron? In J. G. Ponterotto, J. M. Casas, L. A. Suzuki, \& C. M. Alexander (Eds.), Handbook of multicultural counseling. (2nd ed., pp. 542-574). Thousand Oaks, CA: Sage.

Atkinson, D. R., Morten, G., \& Sue, D. W. (1998). Counseling American minorities. Boston: McGraw-Hill. 
*Asner, K. K. (1999). Predictors of mental health among Central American immigrants. Unpublished doctoral dissertation, George Washington University, Washington, D.C. Bachay, J. (1998). Ethnic identity development and urban Haitian adolescents. Journal of Multicultural Counseling and Development, 26(2), 96-109.

*Bacho, R. (1997). Effects of acculturation, ethnic identity commitment, and family coping on Filipino-American family matrons' severity of psychological symptoms and attitudes towards mental health services. Unpublished doctoral dissertation, Florida State University, Tallahassee, FL.

*Barry, D. T. (2000). East Asians in America: Relationships between ethnic identity, selfconstrual, mental health, and acculturation patterns in East Asian immigrants in the United States. Unpublished doctoral dissertation, University of Toledo, $\mathrm{OH}$.

*Basurto, R. (1995). The relationship of ethnic identity to self-esteem and stress as a function of perceived discrimination among Mexican-Americans. Unpublished doctoral dissertation, California School of Professional Psychology, Los Angeles, CA.

Begg, C. B. (1994). Publication bias. In H. Cooper and L. V. Hedges (Eds.), The handbook of research synthesis (pp. 399-409). New York: Russell Sage Foundation.

*Beiser, M. N. M. N., \& Hou, F. (2006). Ethnic identity, resettlement stress and depressive affect among Southeast Asian refugees in Canada. Social Science and Medicine, 63(1), 137-150. doi:10.1016/j.socscimed.2005.12.002

Berman, A. M., Schwartz, S. J., Kurtines, W. M., \& Berman, S. L. (2001). The process of exploration in identity formation: The role of style and competence. Journal of Adolescence, 24, 513-528. doi:10.1006/jado.2001.0386 
Berry, J. W. (2003). Conceptual approaches to understanding acculturation. In K. M. Chun, P. B. Organista, \& G. Marín (Eds.), Acculturation: Advances in theory, measurement, and applied research (pp. 17-38). Washington, DC: American Psychological Association.

Berzonsky, M. D. (1989). Identity style: Conceptualization and measurement. Journal of Adolescent Research, 4, 268-282. doi:10.1177/074355488943002

*Bhadha, B. R. (2001). Effects of parenting style and ethnic identity on European American and Asian Indian adolescents' academic competence and self-esteem. Unpublished doctoral dissertation, University of Southern California, Los Angeles, CA.

*Bhargava, A. (2007). Testing sociocultural and ethnocultural models of eating disorder symptomatology in Asian Indian-American women. Unpublished doctoral dissertation, Washington State University, Pullman, WA.

*Biggs, M. A. (1998). Puerto Rican adolescents' cultural orientation: Contextual determinants and psychosocial outcomes. Unpublished doctoral dissertation, Boston University, MA.

*Blash, R. R., \& Unger, D. G. (1995). Self-concept of African-American male youth: Selfesteem and ethnic identity. Journal of Child and Family Studies, 4(3), 359-373. doi:10.1007/BF02233968

*Bosarge, J. S. (2007). Burnout, coping styles, and ethnic identity: A study of Mexican American school counselors. Unpublished Doctoral Dissertation. New Mexico State University, Las Cruces, NM.

*Bracey, J. R., Bamaca, M. Y. \& Umana-Taylor, A. J. (2004). Examing ethnic identity and selfesteem among biracial and monoracial adolescents. Journal of Youth and Adolescence, 33(2), 123-132. doi:10.1023/B:JOYO.0000013424.93635.68 
*Bruner, L. P. (2004). Understanding life satisfaction among Korean American adults: A stress and coping approach. Unpublished Doctoral Dissertation. Georgia State University, Atlanta, GA.

Burlew, A. (2000). Ethnic and racial identity: Racial identity. In A. E. Kazdin (Ed.): Encyclopedia of Psychology, Vol. 3 (pp. 259-263). Washington, DC: American Psychological Association. doi:10.1037/10518-123.

*Byers, L. G. (2005). Depression, discrimination, trauma, and American Indian ethnic identity. Unpublished doctoral dissertation, Washington University, Saint Louis, MO.

*Canabal, I. (1995). Latino group identities, collective and personal self-esteem. Unpublished doctoral dissertation, University of Maryland, Baltimore, MD.

*Carlson, C., Uppal, S., \& Prosser, E. C. (2000). Ethnic differences in processes contributing to the self-esteem of early adolescent girls. Journal of Early Adolescence, 20(1), 44-67. doi:10.1177/0272431600020001003

*Carter, M. M., Sbrocco, T., Lewis, E. L., \& Friedman, E. K. (2001). Parental bonding and anxiety: Differences between African American and European American college students. Journal of Anxiety Disorders, 15(6), 555-569. doi:10.1016/S0887-6185(01)00081-0

*Carter, M. M., Sbrocco, T., Miller, O., Suchday, S., Lewis, E. L., \& Freedman, R. E. K. (2005). Factor structure, reliability, and validity, of the Penn State Worry Questionnaire: Differences between African-American and White-American college students. Anxiety Disorders, 19(8), 827-843. doi:10.1016/j.janxdis.2004.11.001

*Chang, T. (1999). The relation of cognitive complexity to ethnic identity and adjustment. Unpublished doctoral dissertation, University of Illinois at Urbana-Champaign. 
*Chapell, M. S. (1999). Development of deductive reasoning, ethnic identity, and self-esteem in African American adolescents. Unpublished doctoral dissertation, Temple University, Philadelphia, PA.

*Charlot-Swilley, D. (1997). The centrality of mutuality, Africentric values, and ethnic identity on the socio-emotional functioning of adolescent girls. Unpublished doctoral dissertation, Howard University, Washington, D.C.

*Chatman, J. D. (2006). Risk and resiliency among inner city minority adolescents: A study of coping and ethnic identity. Unpublished doctoral dissertation, University of California Los Angeles, Los Angeles, CA.

*Chow, J. (2003). The relationship of racial, ethnic, and gender identity attitudes to indicators of mental health and self-esteem of Asian American women. Unpublished doctoral dissertation, Indiana University, Bloomington, IN.

*Christensen, M. L. (1999). The role ethnic identity and family support in the psychological well-being of American Indian elders: A comparison of men and women in reservation and urban settings. Unpublished doctoral dissertation, Loyola University, Chicago, IL.

*Cislo, A. M. (2008). Ethnic identity and self-esteem: Contrasting Cuban and Nicaraguan young adults. Hispanic Journal of Behavioral Sciences, 30(2), 230-250. doi:10.1177/0739986308315297

Cook, T. D., \& Leviton, L. (1982). Reviewing the literature: A comparison of traditional methods with meta-analysis. Journal of Personality, 48, 449-472. doi:10.1111/j.1467-6494.1980.tb02379.x

Cooper, H. (1998). Synthesizing research: A guide for literature reviews (3rd ed.). Thousand Oaks, CA: Sage. 
Cooper, H., \& Hedges, L. V. (Eds.). (1994). The handbook of research synthesis. New York: Russell Sage.

*Creagh-Kaiser, M. G. (2003). The influence of ethnic idenity, gender and trait anxiety on career decision-making self-efficacy for White and racial/ethnic minority students. Unpublished doctoral dissertation, Seton Hall University, South Orange, NJ.

Cross, W. E., Jr. (1971). Negro-to-Black conversion experience: Toward a psychology of black liberation. Black World, 20(9), 13-27.

Cross, W. E., Jr., \& Cross, T. B. (2008). Theory, research, and models. In S. Quintana \& C. McKown (Eds.) Handbook of race, racism, and child development. (pp. 154-181). New Jersey: John Wiley and Sons.

Cokley, K. (2007). Critical issues in the measurement of ethnic and racial identity: A referendum on the state of the field. Journal of Counseling Psychology, 54(3), 224-234. doi:10.1037/0022-0167.54.3.224

*Daniels, D. D. (2004). Psycho-social predictors of academic success for urban AfricanAmerican adolescents. Unpublished doctoral dissertation, Loyola University Chicago, Chicago, IL.

*Dejud, C. (2007). The relationship among ethnic identity, psychological well-being, academic achievement, and intergroup competence of school-age Hispanic/Latino youth. Unpublished doctoral dissertation, University of Arizona, Tucson, AZ.

*Delva, S. (2005). Exploring the relation of ethnic identity and biculturality on the psychological well-being of second-generation Haitians. Unpublished doctoral dissertation, New Mexico State University, Las Cruces, NM. 
*Des Jardins, K. S. (1996). Racial/ethnic identity development and self concept in adopted Korean women. Unpublished doctoral dissertation, Boston University, Boston, MA.

*Diwan, S., Jonnalagadda, S. S., \& Balaswamy, S. (2004). Resources predicting positive and negative affect during the experience of stress: A study of older Asian Indian immigrants in the United States. The Gerontologist, 44(5), 605-614.

*Dixon, A. L. (2002). The relationship among ethnic identity, acculturation, mattering, and wellness in minority and non-minority adolescents. Unpublished doctoral dissertation, University of North Carolina at Greensboro, Greensboro, NC.

*Do, V. T. (2006). Asian American men and the media: The relationship between ethnic identity, self-esteem, and the endorsement of stereotypes. Unpublished doctoral dissertation, Alliant International University, Los Angeles, CA.

*Douglas, A. N. (2004). Dissociation as coping: An examination of ethnic differences and racerelated stress. Unpublished doctoral dissertation, University of Connecticut, Storrs, CT.

Du Bois, W. E. B. (1903). The souls of black folk. Chicago: A. C. McClure.

Duval, S. Tweedie, R. (2000b). Trim and fill: A simple funnel-plot based method of testing and adjusting for publication bias in meta-analysis. Biometrics, 56, 455-463. doi:10.1111/j.0006-341X.2000.00455.x

*Edwards, L. M. (2003). Factors contributing to subjective well-being in Mexican-American adolescents. Unpublished doctoral dissertation, University of Kansas, Lawrence, KS.

*Elek-Fisk, E. (1998). The effect of the salience of ethnic or racial identifications and group security on outgroup acceptance. Unpublished doctoral dissertation, State University of New York, Stony Brook, NY. 
*Eng, M. (1982). Toward a general paradigm of majoritry-minority relationships: An exploratory analysis of the relationship of locus of control and individual-system blame attribution to personality characteristics, Chinese American ethnic identity, and psychological symptomatology. Unpublished doctoral dissertation, Wright Institute, Berkeley, CA.

Erikson, E. H. (1959/1980). Identity and the life cycle. New York: International Universities Press.

Fanon, F. (1963). The wretched of the earth. New York: Grove Press.

Fanon, F. (1967). Black skins, white masks. New York: Grove Press.

*Farver, J. M., Narang, S. K., \& Bhadha, B. R. (2002). East meets West: Ethnic identity, acculturation, and conflict in Asian Indian families. Journal of Family Psychology, 16(3), 338-350. doi:10.1037/0893-3200.16.3.338

*Foster, K. (2004). The relations between well being, attitudinal and behavioral factors across three Black identity orientations: Assimilated, Afrocentric, and multicultural. Unpublished doctoral dissertation, City University of New York, New York City, NY.

*French, S. E. (2002). The development of racial and ethnic identity and its relationship to selfesteem among urban adolescents. Unpublished doctoral dissertation, New York University, New York City, NY.

Fuligni, A. J., Witkow, M., \& Garcia, C. (2005). Ethnic identity and the academic adjustment of adolescents from Mexican, Chinese, and European backgrounds. Developmental Psychology, 41(5), 799-811. doi:10.1037/0012-1649.41.5.799 
*Gamst, G., Dana, R. H., Der-Karabetian, A., Aragon, M., Arellano, L. M., \& Kramer, T. (2002). Effects of Latino acculturation and ethnic identity on mental health outcomes. Hispanic Journal of Behavioral Sciences, 24, 479-504. doi:10.1177/0739986302238216

*Gamst, G., Herdina, A., Mondragon, E., Munguia, F., Pleitez, A., Stephens, H., \& Vo, D. (2006). Relationship among respondent ethnicity, ethnic identity, acculturation, and homeless status on a homeless population's functional status. Journal of Clinical Psychology, 62(12), 1485-1501. doi:10.1002/jclp.20323

*Gaudet, S., Clement, R., \& Deuzeman, K. (2005). Daily hassles, ethnic identity and psychological ajustment among Lebanese-Canadians. International Journal of Psychology, 40(3), 157-168. doi:10.1080/00207590444000267

*Gaylord-Harden, N. K., Ragsdale, B. L., Mandara, J., Richards, M. H., \& Petersen, A. C. (2007). Perceived support and internalizing symptoms in African American adolescents: Self-esteem and ethnic identity as mediators. Journal of Youth and Adolescents, 36, 77-88. doi:10.1007/s10964-006-9115-9

*Gilmore, T. E. (2000). Influence of shame, female identity, and ethnic identity on body image across women's life-span. Unpublished doctoral dissertation, Fuller Theological Seminary, Pasadena, CA.

*Gloria, A. M., \& Hird, J. S. (1999). Influences of ethnic and nonethnic variables on the career decision-making self-efficacy of college students. The Career Development Quarterly, 48(2), 157-174.

*Gong, L. (2007). Ethnic identity and identification with the majority group: Relations with national identity and self-esteem. International Journal of Intercultural Relations, 31(4), 503-523. doi:10.1016/j.ijintrel.2007.03.002 
*Gonzalez, N. (2003). Ethnic identity and peer attachment: Factors associated with the adjustment of Latino college freshmen. Unpublished doctoral dissertation, State University of New York, Albany.

*Goodstein, R., \& Ponterotto, J. G. (1997). Racial and ethnic identity: Their relationship and their contribution to self-esteem. Journal of Black Psychology, 23(3), 275-292. doi:10.1177/00957984970233009

*Gotowiec, A. P. (1999). Ethnic identity and self-esteem in native adolescents. Unpublished doctoral dissertation, University of Toronto, Ontario, Canada.

*Graham, B. L. (2001). Resilience among American Indian youth: First Nations' Youth Resilience Study. Unpublished doctoral dissertation, The University of Minnesota, Minneapolis, MN.

*Greene, M. A. (1997). Biculturalism and mental-health among Mexican-American adolescents. Unpublished doctoral dissertation, Temple University, Philadelphia, PA.

Griner, D., \& Smith, T. B. (2006). Culturally adapted mental health interventions: A metaanalytic review. Psychotherapy: Theory, Research, Practice \& Training, 43, 531-548. doi:10.1037/0033-3204.43.4.531

Grotevant, H. D. (1987). Toward a process model of identity formation. Journal of Adolescent Research, 2(3), 203-222. doi:10.1177/074355488723003

*Harrison, P. M. (1997). Racial identification and self-concept issues in biracial (Black/White) adolescent girls. Unpublished doctoral dissertation, Columbia University, New York, NY.

*Hazen, S. L. H. (1994). The relationship between ethnic/racial identity status and ego identity status. Unpublished doctoral dissertation, George Mason University, Fairfax, VA. 
Hedges, L. V., \& Vevea, J. L. (1998). Fixed- and random-effects models in meta-analysis. Psychological Methods, 3, 486-504. doi:10.1037/1082-989X.3.4.486

Helms, J. E. (2007). Some better practices for measuring racial and ethnic identity constructs. Journal of Counseling Psychology, 54(3), 235-246. doi:10.1037/0022-0167.54.3.235

Helms, J. (1990). Black and White racial identity: Theory, research, and practice. New York: Greenwood Press.

Helms, J. E. (1984). Toward a theoretical explanation of the effects of race on counseling: A Black and White model. The Counseling Psychologist, 12(3-4), 153-165. doi:10.1177/0011000084124013.

Helms, J. E., \& Talleyrand, R. (1997). Race is not ethnicity. American Psychologist, 52(11), 1246-1247. doi:10.1037/0003-066X.52.11.1246

*Holmes, K. J. (2007). The effects of religiousity and ethnic identity on African American preadolescent aggression. Unpublished doctoral dissertation, The University of Alabama, Tuscaloosa, AL.

Hoffman, R. (2006). Gender self-definition and gender self-acceptance in women: Intersections with feminist, womanist, and ethnic identities. Journal of Counseling \& Development, 84, $358-372$.

*Hovey, J. D., Kim, S. E., \& Seligman, L. D. (2006). The influences of cultural values, ethnic identity, and language use on the mental health of Korean American college students. The Journal of Psychology, 140(5), 499-511. doi:10.3200/JRLP.140.5.499-511

Hughes, D., Hagelskamp, C., Way, N., \& Foust, M. (2009). The role of mothers' and adolescents' perceptions of ethnic-racial socialization in shaping ethnic-racial identity among early adolescent boys and girls. Journal of Youth and Adolescence, 38(5), 605-626. 
Hughes, D., Rivas, D. Foust, M., Hagelskamp, C., Gersick, S., \& Way, N. (2008). How to catch a moonbeam: A mixed-methods approach to understanding ethnic socialization in ethnically diverse families. In S. Quintana \& C. McKown (Eds.) Handbook of race, racism, and child development. (pp. 226-277). New Jersey: John Wiley and Sons.

Inman, A., Howard, E., Beaumont, R., \& Walker, J. (2007). Cultural transmission: Influence of contextual factors in Asian Indian immigrant parents' experiences. Journal of Counseling Psychology, 54(1), 93-100. doi:10.1037/0022-0167.54.1.93

*Inoue, S. (1997). Coping with oppression among Japanese American women: Cross-cultural comparisons of coping, cognitive appraisal, ethnic identity, and feminist identity. Unpublished doctoral dissertation, California School of Professional Psychology, Alameda, CA.

*Iwamoto, D. K. (2007). The role of racial identity, ethnic identity, and Asian values as mediators of perceived discrimination and psychological well-being among Asian American college students. Unpublished doctoral dissertation, University of NebraskaLincoln, Lincoln, NE.

*Iyer, D. S. (2000). The contribution of racial teasing and cultural identification in the development of eating pathology in South Asian women. Unpublished doctoral dissertation, New School University, New York City, NY.

*Jo, H. (1998). The influence of African American urban high school students' ethnic identity and coping strategies on academic involvement and psychological adjustment. Unpublished doctoral dissertation, Michigan State University, East Lansing, MI. 
*Jones, J. E. (1999). Multiethnic identity development, psychological adjustment, and parental attachment in adolescence. Unpublished doctoral dissertation, Adelphi University, Garden City, NY.

*Jones, M. D., \& Galliher, R. V. (2007). Ethnic identity and psychosocial functioning in Navajo adolescents. Journal of Research on Adolescence, 17(4), 683-696.

*Joseph, T. X. (1994). The influence of stages of ethnic identification on evaluations of precounseling orientation presentations. Unpublished doctoral dissertation, Fairleigh Dickinson University, Madison, NJ.

*Juang, L. P., Nguyen, H. H., \& Lin, Y. (2006). The ethnic identity, other-group attitudes, and psychosocial functioning of Asian Americans emerging adults from two contexts. Journal of Adolescent Research, 21(5), 542-568. doi:10.1177/0743558406291691

*Kamins, D. J. (2003). Acculturation and ethnic identity: Correlates of perceived attractiveness, body image, and eating behaviors among Latinas. Unpublished doctoral dissertation, Alliant International University, San Francisco, CA.

*Kaneshiro, E. N. (1996). Multiculturalism and the model minority: Japanese Americans' ethnic identity and psychosocial adjustment. Unpublished doctoral dissertation, Claremont Graduate School, Claremont, CA.

*Kaslow, N. J., Price, A. W., Wyckoff, S., Grall, M. B., Sherry, A., Young, S., Scholl, L., Upshaw, V. M., Rashid, A., Jackson, E. B., \& Bethea, K. (2004). Person factors associated with suicidal behavior among African American women and men. Cultural Diversity and Ethnic Minority Psychology, 10(1), 5-22. doi:10.1037/1099-9809.10.1.5 
*Kauh, T. J. (2005). Ethnic identity developmental process and outcome: Implications for the health and well-being of Asian American young adults. Unpublished doctoral dissertation, Pennsylvania State University, University Park, PA.

*Kekwaletswe, T. C. (2007). Africentric values and ethnic identity as predictors of HIV risk behavior, substance use, and psychopathology among African American girls seeking outpatient psychiatric services. Unpublished doctoral dissertation, Rosalind Franklin University of Medicine \& Science, North Chicago, IL.

*Kiang, L., Yip, T., Gonzales-Backen, M., Witkow, M., \& Fuligni, A. J. (2006). Ethnic identity and the daily psychological well-being of adolescents from Mexican and Chinese backgrounds. Child Development, 77(5), 1338-1350. doi:10.1111/j.14678624.2006.00938.x

*Kim, S., \& Rew, L. (1994). Ethnic identity, role integration, quality of life, and depression in Korean-American women. Archives of Psychiatric Nursing, 8(6), 348-356. doi:10.1016/0883-9417(94)90003-5

*Kim, G. S. (2006). The co-construction of racial and ethnic identities and self-esteem in Asian American youth: Effects of belonging and exclusion. Unpublished doctoral dissertation, University of Massachusetts Boston, Boston, MA.

*Kim-Bae, L. S. (1999). Cultural identity as a mediator of acculturative stress and psychological adjustment in Vietnamese American adolescents. Unpublished doctoral dissertation, Arizona State University, Tempe, AZ.

*Kwan, K. K. (1996). Ethnic identity and cultural adjustment difficulties of Chinese Americans. Unpublished doctoral dissertation, University of Nebraska, Lincoln, NE. 
*Lamborn, S. D., \& Nguyen, D. T. (2004). African American adolescents' perceptions of family interactions: Kinship support, parent-child relationships, and teen adjustment. Journal of Youth and Adolescence, 33(6), 547-558. doi:10.1023/B:JOYO.0000048068.55441.d6

*Larson, L.A. (1995). Black-White biracial adolescents: Ethnic identity, self-label, and adaptive functioning. Unpublished doctoral dissertation. California School of Professional Psychology, Los Angeles, CA.

*Laurent, M. G. (1997). Gender role conflict, cultural identity, and self-esteem among AfricanAmerican men. Unpublished doctoral dissertation, University of Southern California, Los Angeles, CA.

*Lavish, L. A. (2007). Global self-esteem as a mediating variable in the relationship between cultural process variables, perceived career barriers, and job procurement self-efficacy among American Indians. Unpublished doctoral dissertation, University of MissouriKansas City, Kansas City, MO.

*Lee, R. M. (2005). Resilience against discrimination: Ethnic identity and other-group orientation as protective factors for Korean Americans. Journal of Counseling Psychology, 52(1), 36-44. doi:10.1037/0022-0167.52.1.36

*Lee, R. M., \& Yoo, H. C. (2004). Structure and measurement of ethnic identity for Asian American college students. Journal of Counseling Psychology, 51(2), 263-269. doi:10.1037/0022-0167.51.2.263

*Lee, S. (2001). Impact of ethnic identity on psychological well-being among Korean Americans in the United States. Unpublished doctoral dissertation, State University of New York at Albany, Albany, NY. 
*Lewis, C. M. (1997). Gifted Asian-American adolescent females. Unpublished doctoral dissertation, California School of Professional Psychology, Los Angeles, CA.

*Lewis, D. K. (1998). Kinship, self-concept, and self-identity: Roles in racial identity, spirituality, and psychopathology in African-American and Caucasian-American women.Unpublished doctoral dissertation, Virginia Commonwealth University, Richmond, VA.

Lipsey, M. W., \& Wilson, D. B. (2001). Practical meta-analysis. Thousand Oaks, CA: Sage.

*Lopez, I. (2005). "I feel pretty, oh so pretty": Ethnic identity, phenotype, and adjustment among mainland Puerto Rican women. Unpublished doctoral dissertation, Kent State University, Kent, $\mathrm{OH}$.

*Lorenzo-Hernandez, J., \& Ouellette, S. C. (1998). Ethnic identity, self-esteem, and values in Dominicans, Puerto Ricans, and African Americans. Journal of Applied Social Psychology, 28(21), 2007-2024. doi:10.1111/j.1559-1816.1998.tb01358.x

Marcia, J. E., Waterman, A. S., Matteson, D. R., Archer, S. L., \& Orlofsky, J. L. (1993). Ego identity: A handbook for psychosocial research. New York: Springer-Verlag.

Matt, G. E., \& Navarro, A. M. (1997). What meta-analyses have and have not taught us about psychotherapy effects: A review and future directions. Clinical Psychology Review, 17, 1-32. doi:10.1016/S0272-7358(96)00042-6

May, R., \& Yalom, I. (2005). Existential psychotherapy. In R. J. Corsini and D. Wedding (Eds.) Current psychotherapies (7th ed.) (pp. 269-298). Belmont, CA: Thomson Brooks/Cole. 
McCoy, S., \& Major, B. (2003). Group identification moderates emotional responses to perceived prejudice. Personality and Social Psychology Bulletin, 29(8), 1005-1017. doi:10.1177/0146167203253466.

*McCubbin, L. D. (2003). Resilience among native Hawaiian adolescents: Ethnic identity, pscyhological distress and well-being. Unpublished doctoral dissertation, University of Wisconsin-Madison, Madison, WI.

*McDuffie, K. Y. (1997). Social support, community involvement, and ethnic identity development in African American adolescents with mild cognitive disabilities. Unpublished doctoral dissertation, University of Alabama, Birmingham, AL.

*McKnight, L. R. (2003). Depressive symptoms, coping, and ethnic identity in African American college women. Unpublished doctoral dissertation, University of Virginia, Charlottesville.

*McMahon, S. D., \& Watts, R. J. (2002). Ethnic identity in urban African American youth: Exploring links with self-worth, aggression, and other psychosocial variables. Journal of Community Psychology, 30(4), 411-431. doi:10.1002/jcop.10013

*Mohanty, J., Keokse, G., \& Sales, E. (2006). Family cultural socialization, ethnic identity, and self-esteem: Web-based survey of international adult adoptees. Journal of Ethnic and Cultural Diversity in Social Work, 15(3/4), 153-172. doi:10.1300/J051v15n03_07

*Mukoyama, T. H. J. (1998). Effects of heritage combination on ethnic identity, self-esteem, and adjustment among American biethnic adults. Unpublished doctoral dissertation, California School of Professional Psychology, Los Angeles, CA.

Mullen, B. (1989). Advanced BASIC Meta-analysis. Hillside, NJ: Erlbaum.

Myers, H. (2009). Ethnicity- and socio-economic status-related stresses in context: An integrative review and conceptual model. Journal of Behavioral Medicine, 32(1), 9-19. 
*Nagara, A. (2005). Psychological health and mental health services utilization in Asian Indians in the United States. Unpublished doctoral dissertation, Central Michigan University, Mount Pleasant, MI.

*Negy, C., Shreve, T. L., Jensen, B. J., \& Uddin, N. (2003). Ethnic identity, self-esteem, and ethnocentrism: A study of social identity versus multicultural theory of development. Cultural Diversity and Ethnic Minority Psychology, 9(4), 333-344 doi:10.1037/10999809.9.4.333

Neville, H., \& Mobley, M. (2001). Social identities in contexts: An ecological model of multicultural counseling psychology processes. The Counseling Psychologist, 29(4), 471486. doi:10.1177/0011000001294001

*Newman, D. L., Sontag, L. M., \& Salvato R. (2006). Psychosocial aspects of body mass and body image among rural American Indian adolescents. Journal of Youth and Adolescence, 35(2), 281-291. doi:10.1007/s10964-005-9011-8

*Newsom, K. C. (2004). The relationship between ethnic identity development and self-concept of African-American preadolescent youth. Unpublished doctoral dissertation, University of Kentucky, Lexington, KY.

*Noh, S., Beiser, M., Kaspar, V., Hou, F., \& Rummens, J. (1999). Perceived racial discrimination, depression, and coping: A study of Southeast Asian refugees in Canada. Journal of Health and Social Behavior, 40(3), 193-207. doi:10.2307/2676348

*Northwood, A. K. (1996). Trauma exposure, post-traumatic symptoms, and identity in adolescent survivors of massive childhood trauma. Unpublished doctoral dissertation, University of Minnesota, Minneapolis, MN. 
*O'Donnell, L., O'Donnell, C., Wardlaw, D. M., \& Stueve, A. (2004). Risk and resiliency factors influencing suicidality among urban African American and Latino youth. American Journal of Community Psychology, 33(1/2), 37-49.

doi:10.1023/B:AJCP.0000014317.20704.0b

Ong, A. D., Phinney, J. S., \& Dennis, J. (2006). Competence under challenge: Exploring the protective influence of parental support and ethnic identity in Latino college students. Journal of Adolescence, 29, 961-979.

*Orellana, D. C. (2004). Mediating and moderating processes in the relationship between sociocultural stress and mental health for Latina/o students at a predominately White university. Unpublished doctoral dissertation, Michigan State University, East Lansing.

Outten, H., Schmitt, M., Garcia, D., \& Branscombe, N. (2009). Coping options: Missing links between minority group identification and psychological well-being. Applied Psychology: An International Review, 58(1), 146-170.

Ozer, D. (1985). Correlation and the coefficient of determination. Psychological Bulletin, 97(2), 307-315. doi:10.1037/0033-2909.97.2.307.

*Pallock, L. L. (2003). The importance of fitting in: An examination of the influence of coping with diversity and cultural identity on educational and psychological outcomes among adolescents in the United States and Kazakstan. Unpublished doctoral dissertation, University of Wisconsin-Madison, Madison, WI.

*Parisi, M. A. (1997). Ethnic identity and its relationship to self-esteem and attitudes toward other ethnic groups. Unpublished doctoral dissertation, Fordham University, New York. 
*Park-Adams, J. (1997). The relationship between ethnic identity and psychological adjustment among Korean Americans. Unpublished doctoral dissertation, California School of Professional Psychology, Alameda, CA.

Ponterotto, J., \& Park-Taylor, J. (2007). Racial and ethnic identity theory, measurement, and research in counseling psychology: Present status and future directions. Journal of Counseling Psychology, 54(3), 282-294. doi:10.1037/0022-0167.54.3.282

*Paschall, M. J., \& Flewelling, R. L. (1997). Measuring intermediate outcomes of violence prevention programs targeting African-American male youth: An exploratory assessment of the psychometric properties of six psychosocial measures. Health Education Research, 12(1), 117-128. doi:10.1093/her/12.1.117

*Perez, A. M. (1998). Migration and mental health among Dominican immigrants living in New York City: A comparison of two migration-mental health models. Unpublished doctoral dissertation, Fordham University, New York, NY.

*Petersons, M., Rojhani, A., Steinhaus, N., \& Larkin, B. (2000). Effect of ethnic identity on attitudes, feelings, and behaviors toward food. Eating Disorders, 8(3), 207-219. doi:10.1080/10640260008251228

*Phan, T. \& Tylka, T. L. (2006). Exploring a model and moderators of disordered eating with Asian American college women. Journal of Counseling Psychology, 53(1), 36-47. doi:10.1037/0022-0167.53.1.36

*Phillips, L. D. (1994). Adolescent ethnic identity and adjustment: Relation to ethnic characteristics of the peer context. Unpublished doctoral dissertation, Temple University, Philadelphia, PA. 
Phinney, J. S. (2006). Ethnic identity exploration in emerging adulthood. In J. Arnett and J. Tanner (Eds.) Emerging adults in America: Coming of age in the 21st century (pp. 117134). Washington, DC: American Psychological Association. doi:10.1037/11381-005

Phinney, J. S. (2000). Ethnic and racial identity: Ethnic identity. In A. E. Kazdin (Ed.), Encyclopedia of psychology (vol. 3, pp. 254-259). Washington, D.C.: American Psychological Association. doi:10.1037/10518-122

Phinney, J. S. (1996). When we talk about American ethnic groups, what do we mean? American Psychologist, 51(9), 918-927. doi:10.1037/0003-066X.51.9.918

*Phinney, J. S. (1992). The Multigroup Ethnic Identity Measure: A new scale for use with diverse groups. Journal of Adolescent Research, 7(2), 156-176. doi:10.1177/074355489272003

Phinney, J. S. (1989). Stages of ethnic identity development in minority group adolescents. Journal of Early Adolescence, 9(1-2), 34-49. doi:10.1177/0272431689091004

*Phinney, J. S., \& Alipuria, L. L. (1990). Ethnic identity in college students from four ethnic groups. Journal of Adolescence, 13(2), 171-183. doi:10.1016/0140-1971(90)90006-S

*Phinney, J. S., Cantu, C. L., \& Kurtz, D. A. (1997). Ethnic and American identity as predictors of self-esteem among African American, Latino, and White adolescents. Journal of Youth and Adolescence, 26(2), 165-185. doi:10.1023/A:1024500514834

*Phinney, J. S., \& Chavira, V. (1992). Ethnic identity and self-esteem: An exploratory longitudinal study. Journal of Adolescence, 15(3), 271-281. doi:10.1016/01401971(92)90030-9

*Phinney, J. S., Ferguson, D. L., \& Tate, J. D. (1997). Intergroup attitudes among ethnic minority adolescents: A causal model. Child Development, 68(5), 955-969. 
doi: $10.2307 / 1132044$

Phinney, J. S., Horenczyk, G., Liebkind, K., \& Vedder, P. (2001). Ethnic identity, immigration, and well-being: An interactional perspective. Journal of Social Issues, 57(3), 493-510. doi:10.1111/0022-4537.00225

*Phinney, J. S., Madden, T., \& Santos, L. J. (1998). Psychological variables as predictors of perceived ethnic discrimination among minority and immigrant adolescents. Journal of Applied Social Psychology, 28(11), 937-953. doi:10.1111/j.1559-1816.1998.tb01661.x

Phinney, J. S., \& Ong, A. (2007). Conceptualization and measurement of ethnic identity: Current status and future directions. Journal of Counseling Psychology, 54(3), 271-281. doi:10.1037/0022-0167.54.3.271

*Pittenger, S. M. (1998). The relationship between ethnic identity, self-esteem, emotional wellbeing and depression among Lakota/Dakota Sioux adolescents. Unpublished doctoral dissertation, Old Dominion University, Norfolk, VA.

Ponterotto, J., \& Mallinckrodt, B. (2007). Introduction to the special section on racial and ethnic identity in counseling psychology: Conceptual and methodological challenges and proposed solutions. Journal of Counseling Psychology, 54(3), 219-223.

doi:10.1037/0022-0167.54.3.219

Ponterotto, J., \& Park-Taylor, J. (2007). Racial and ethnic identity theory, measurement, and research in counseling psychology: Present status and future directions. Journal of Counseling Psychology, 54(3), 282-294. doi:10.1037/0022-0167.54.3.282

*Prelow, H. M., Bowman, M. A. \& Weaver, S. R. (2007). Predictors of psychosocial well-being in urban African American and European American youth: The role of ecological factors. Journal of Youth and Adolescence, 36(4), 543-553. doi:10.1007/s10964-006-9038-5 
*Pugh-Lilly, A. O. (2000). Understanding aggressive behavior in Black adolecent girls: An examination of causal attributions, perceptions of coping, problem solving appraisal, selfesteem and ethnic identity. Unpublished doctoral dissertation, University of MissouriColumbia, Columbia, MO.

*Quinones, M. E. (1996). Latina college students: The relationship among ethnic identity, acculturation, gender roles, and psychological well-being. Unpublished doctoral dissertation, City University of New York, New York, NY.

Quintana, S. (2007). Racial and ethnic identity: Developmental perspectives and research. Journal of Counseling Psychology, 54(3), 259-270.

*Ramirez, R. L. (1997). The relationship between acculturation, ethnic identity, and self-esteem of Midwest Mexican-American university students. Unpublished doctoral dissertation, University of Wisconsin-Madison, Madison, WI.

*Reddy, D. C. (2002). The relationship of ethnic identity, acculturation, and psychological adjustment among Asian Indian immigrants. Unpublished doctoral dissertation, University of Missouri- Kansas City, Kansas City, MO.

*Resnicow, K., Soler, R. E., Braithwaite, R. L., Selassie, M. B., \& Smith, M. (1999). Development of a racial and ethnic identity scale for African American adolescents: The Survey of Black Life. Journal of Black Psychology, 25(2), 171-188. doi:10.1177/0095798499025002003

*Rivas-Drake, D., Hughes, D., \& Way, N. (2008). A closer look at peer discrimination, ethnic identity, and psychological well-being among urban Chinese American sixth graders. Journal of Youth and Adolescence, 37(1), 12-21. doi:10.1007/s10964-007-9227-x 
*Roberts, D. D. (1997). Racial/ethnic identity as a buffer to discrimination among low income African-American adolescents: An examination of academic performance. Unpublished doctoral dissertation, Temple University, Philadelphia, PA.

*Roberts, R. E., Phinney, J. S., Masse, L. C., Chen, Y. R., Roberts, C. R., \& Romero, A. (1999). The structure of ethnic identity of young adolescents from diverse ethnocultural groups. Journal of Early Adolescence, 19(3), 301-322. doi:10.1177/0272431699019003001

Rogers, C. (1961). On becoming a person. Oxford England: Houghton Mifflin.

*Romero, A. J., \& Roberts, R. E. (2003). The impact of multiple dimensions of ethnic identity on discrimination and adolescents' self-esteem. Journal of Applied Social Psychology, $33(11), 2288-2305$.

doi:10.1111/j.1559-1816.2003.tb01885.x

*Rosario, J. (1999). Puerto Rican youth "at risk": Impact of ethnic identity and self-esteem on academic success. Unpublished doctoral dissertation, Pace University, New York City, NY.

*Rosen, M. C. (2004). Beyond body dissatisfaction: The relationship among attachment, selfesteem, body dissatisfaction and ethnic identity in Asian American and European American women. Unpublished doctoral dissertation, Alliant International University, Los Angeles, CA.

Ruiz, A. (1990). Ethnic identity: Crisis and resolution. Journal of Multicultural Counseling and Development, 18(1), 29-40.

*Ryu, J. (2004). The relationship between ethnic identity and self-esteem of academically high achieving Korean-American adolescents. Unpublished doctoral dissertation, Columbia University, New York, NY. 
*Saavedra, R. (1994). Alienation of Latino medical students: The effect of acculturation, ethnic identity and minority student stressors. Unpublished doctoral dissertation, University of Houston, Houston, TX.

*Santana, E. (1994). Interaction effects between ethnic identity and academic achievement among adolescent ethnic minorities. Unpublished doctoral dissertation, University of Massachusetts, Amherst, MA.

*Sasson, S. (2001). The impact of ethnic identity upon the adjustment and satisfaction of Jewish and African American residents in a long-term care facility. Social Work in Health Care, 33(2), 89-104. doi:10.1300/J010v33n02_06

*Schmidt, C. (2006). Racial/ethnic identity formation and ego development. Unpublished doctoral dissertation, Washington State University, Pullman, WA.

*Schneider, M. E. (1995). How ethnic identity functions as a group identity to affect self-esteem. Unpublished doctoral dissertation, State University of New York, Buffalo, NY.

*Schwartz, S. J., Zamboanga, B. L., \& Jarvis, L. H. (2007). Ethnic identity and acculturation in Hispanic early adolescents: Mediated relationships to academic grades, prosocial behaviors, and externalizing symptoms. Cultural Diversity and Ethnic Minority Psychology, 13(4), 364-373. doi:10.1037/1099-9809.13.4.364

Sellers, R., \& Shelton, J. (2003). The role of racial identity in perceived racial discrimination. Journal of Personality and Social Psychology, 84(5), 1079-1092. doi:10.1037/00223514.84.5.1079.

*Setty, P. (2006). Relationship between ethnic identity and self-esteem in second generation Asian-Indians. Unpublished doctoral dissertation. The Chicago School of Professional Psychology, Chicago, IL. 
*Shibazaki, K. (1999). Ethnic identity, acculturation, perceived discrimination, and college adjustment in Mexican Americans. Unpublished doctoral dissertation, Texas Tech University, Lubbock, TX.

*Shrake, E. K., \& Rhee, S. (2004). Ethnic identity as a predictor of problem behaviors among Korean American adolescents. Adolescence, 39(155), 601-622.

*Siegel, J. M., Yancey, A., \& McCarthy, W. J. (2000). Overweight and depressive symptoms among African-American women. Preventive Medicine, 31, 232-240. doi:10.1006/pmed.2000.0712

*Sieger, K., \& Renk, K. (2007). Pregnant and parenting adolescents: A study of ethnic identity, emotional and behavioral functioning, child characteristics, and social support. Journal of Youth and Adolescence, 36(4), 567-581. doi:10.1007/s10964-007-9182-6

*Smith, E. P., \& Brookins, C. C. (1997). Toward the development of an ethnic identity measure for African American youth. Journal of Black Psychology, 23(4), 358-377. doi:10.1177/00957984970234004

*Smith, F. D. (2003). Ethnic identity development among African American adolescents: The supportive contexts of family and peers. Unpublished doctoral dissertation, University of Virginia, Charlottesville, VA.

Smith, T. B. (2010). Culturally congruent practices in counseling and psychotherapy: A review of research. In J. G. Ponterotto, J. M. Casas, L. A. Suzuki, \& C. M. Alexander (Eds.), Handbook of multicultural counseling. (3rd ed., pp. 439-450). Thousand Oaks, CA: Sage. 
*Smith, Y. K. (2006). Relationship between ethnic identity, level of accomplishment and selfesteem in a group of African American individuals. Unpublished doctoral dissertation, Alliant International University, Los Angeles, CA.

Syed, M., \& Azmitia, M. (2010). Narrative and ethnic identity exploration: A longitudinal account of emerging adults' ethnicity-related experiences. Developmental Psychology, 46, 208-219. doi:10.1037/a0017825.

Syed, M., \& Azmitia, M. (2008). A narrative approach to ethnic identity in emerging adulthood: Bringing life to the identity status model. Developmental Psychology, 44, 1012-1027. doi:10.1037/0012-1649.44.4.1012.

*Sobansky, R. R. B. (2003). Ethnic identity and psychological well-being among youth in residential treatment: Exploring links with school success and psychological distress. Unpublished doctoral dissertation, University of Nebraska, Lincoln, NE.

Sue, S. (1999). Science, ethnicity, and bias: Where have we gone wrong?. American Psychologist, 54(12), 1070-1077. doi:10.1037/0003-066X.54.12.1070.

Supple, A., Ghazarian, S., Frabutt, J., Plunkett, S., \& Sands, T. (2006). Contextual influences on Latino adolescent ethnic identity and academic outcomes. Child Development, 77(5), 1427-1433. doi:10.1111/j.1467-8624.2006.00945.x

*Susberry, T. S. (2004). Racial identification and ethnic identity in Louisiana Creole people of color. Unpublished doctoral dissertation, University of Houston, Houston, TX.

Suzuki, L. A., Alexander, C. M., Lin, P. Y., \& Duffy, K. M. (2006). Psychopathology in the schools: Multicultural factors that impact assessment and intervention. Psychology in the Schools, 43(4), 429-438. doi:10.1002/pits.20157 
*Swenson, R. R., \& Prelow, H. M. (2005). Ethnic identity, self-esteem, and perceived efficacy as mediators of the relation of supportive parenting to psychosocial outcomes among urban adolescents. Journal of Adolescence, 28(4), 465-477. doi:10.1016/j.adolescence.2004.09.005

Tajfel, H. \& Turner, J. (1986). The social identity theory of intergroup behavior. In S. Worchel \& W. Austin (Ed.). Psychology of intergroup relations (pp. 7-24). Chicago: Nelson-Hall.

*Tatman, S. M. (1996). Racial, cultural, and gender differences in relatedness and self definition among young adults. Unpublished doctoral dissertation, Pacific Graduate School of Psychology, Palo Alto, CA.

*Terrell, B. P. (2005). The impact of ethnic socialization and ethnic identity on the self-esteem and parenting attitudes of African American fathers. Best Practices in Mental Health, $1(1), 86-104$.

*To, K. V. (1999). The relationship of ethnic identity and self-esteem among Vietnamese American college students. Unpublished doctoral dissertation, California School of Professional Psychology, Los Angeles, CA.

*Tovar-Murray, D. (2004). Exploring the relationship between race-related stress, identity and well-being among African Americans.Unpublished doctoral dissertation, Western Michigan University, Kalamazoo, MI.

*Tremayne, K. J. (1997). The relationship between self-esteem, psychological adjustment and ethnic identity among biracial Japanese American/Caucasian adults. Unpublished doctoral dissertation, Pepperdine University, Malibu, CA.

Tsai, J., Chentsova-Dutton, Y., \& Wong, Y. (2002). Why and how we should study ethnic identity, acculturation, and cultural orientation. In G. C. Nagayama Hall and S. Okazaki 
(Eds.): Asian American psychology: The science of lives in context (pp. 41-65).

Washington, DC: American Psychological Association. doi:10.1037/10473-002

*Tsoi-Pullar, M. S. (1994). Acculturation and psychological well-being among Chinese-

American college students. Unpublished doctoral dissertation, University of Minnesota, Minneapolis, MN.

Trimble, J. (2007). Prolegomena for the connotation of construct use in the measurement of ethnic and racial identity. Journal of Counseling Psychology, 54(3), 247-258. doi:10.1037/0022-0167.54.3.247

*Turnage, B. F. (1998). A study of four factors that influence an African American female adolescent's global self-esteem. Unpublished doctoral dissertation, Tulane University, New Orleans, LA.

*Turnage, B. F. (2004). Influences on adolescent African American females' global self-esteem: Body image and ethnic identity. Journal of Ethnic and Cultural Diversity in Social Work, 13(4), 27-45. doi:10.1300/J051v13n04_02

Turner, J. C., Hogg, M., Oakes, P. J., Reicher, S. D., \& Wetherell, M. (1987). Rediscovering the social group: A self-categorization theory. Oxford: Blackwell.

*Umaña-Taylor, A. J., Yazedjian, A., \& Bamaca-Gomez, M. (2004). Developing the ethnic identity scale using Ericksonian and social identity perspectives. Identity: An International Journal of Theory and Research, 4(1), 9-38. doi:10.1207/S1532706XID0401_2.

*Umaña-Taylor, A. J. (2004). Ethnic identity and self-esteem: Examining the role of social context. Journal of Adolescence, 27(2), 139-146. doi:10.1016/j.adolescence.2003.11.006 
*Umaña-Taylor, A. J., \& Updegraff, K. A. (2007). Latino adolescents' mental health: Exploring the interrelations among discrimination, ethnic identity, cultural orientation, self-esteem, and depressive symptoms. Journal of Adolescence, 30(4), 549-567.

doi:10.1016/j.adolescence.2006.08.002

*Umaña-Taylor, A. J., \& Shin, N. (2007). An examination of ethnic identity and self-esteem with diverse populations: Exploring variations by ethnicity and geography. Cultural Diversity and Ethnic Minority Psychology, 13(2), 178-186. doi:10.1037/10999809.13.2.178

*Umana-Taylor, A. J., Vargas-Chanes, D., Garcia, C. D., \& Gonzales-Backen, M. (2008). A longitudinal examination of Latino adolescents' ethnic identity, coping with discrimination, and self-esteem. Journal of Early Adolescence, 28(1), 16-50. doi:10.1177/0272431607308666

*Utsey, S. O., Chae, M. H., Brown, C. F., \& Kelly, D. (2002). Effect of ethnic group membership on ethnic identity, race-related stress, and quality of life. Cultural Diversity and Ethnic Minority Psychology, 8(4), 366-377. doi:10.1037/1099-9809.8.4.367

*Van Buren, E. (2004). School experiences among African-American and Latino adolescents: Effects on ethnic identity and school adjustment. Unpublished doctoral dissertation, University of California Los Angeles, Los Angeles, CA.

*Vuong, T. D. (2004). Ethnic identity, acculturation and mental health concerns in ChineseAmericans in the U.S. Unpublished doctoral dissertation, Pacific Graduate School of Psychology, Palo Alto, CA.

*Walker, R. L. (2002). An investigation of acculturative stress and ethnic identification as risk factors for suicidal ideation in African-American vs. Anglo-American men and women: 
The moderating effects of religiosity and social support. Unpublished doctoral dissertation, Florida State University, Tallahassee, FL.

*Walker, R. L., Wingate, L. R., Obasi, E. M., \& Joiner, T. E. (2008). An empirical investigation of acculturative stress and ethnic identity as moderators for depression and suicidal ideation in college students. Cultural Diversity and Ethnic Minority Psychology, 14(1), 75-82. doi:10.1037/1099-9809.14.1.75

*Wallen, V. O. (2001). Ethnic identity, self-esteem and academic factors in second-generation post-1970 Jamaican immigrants. Unpublished doctoral dissertation, Florida International University, Miami, FL.

*Ware, A., (2006). Latina mothers' parenting and girls' anxiety and depression in an urban sample: Associations with ethnic identity and neighborhood context. Unpublished doctoral dissertation, City University of New York, NY.

*Webb-Msemaji, R. (1996). The impact of African self-consciousness, ethnic identity, and racial mistrust on the self-esteem of African American adolescents. Unpublished doctoral dissertation, California School of Professional Psychology, Los Angeles, CA.

*Weathersby, D. A. (2007). Exploring the quality of life of Black women: Within group difference on race related stress, racial identity, and coping. Unpublished doctoral dissertation, Loyola University, Chicago, IL.

*West, A. E. (2004). The experience of social anxiety in Native American adolescents. Unpublished doctoral dissertation, University of Virginia, Charlottesville, VA. *White, C. L., \& Burke, P. J. (1987). Ethnic role identity among Black and White college students: An interactionist approach. Sociological Perspectives, 30(3), 310-331. 
*Wong, C. A., Eccles, J. S., \& Sameroff, A. (2003). The influence of ethnic discrimination and ethnic identification on African American adolescents' school and socioemotional adjustment. Journal of Personality, 71(6), 1197-1232. doi:10.1111/1467-6494.7106012

*Worrell, F. C. (2007). Ethnic identity, academic achievement, and global self-concept in four groups of academically talented adolescents. Gifted Child Quarterly, 51(1), 23-38. doi:10.1177/0016986206296655

*Yang, J. (2006). The relationship between contextual factors of psychological distress with emotional eating and body weight in Hmong and Hmong American college populations. Unpublished doctoral dissertation, Alliant International University, Fresno, CA.

*Yasui, M., Dorham, C. L., \& Dishion, T. J. (2004). Ethnic identity and psychological adjustment: A validity analysis for European American and African American adolescents. Journal of Adolescent Research, 19(6), 807-825. doi:10.1177/0743558403260098

*Ying, Y. W., \& Lee, P. A. (2006). The contribution of ethnic and American identities to the migrant's self-esteem: An empirical investigation. International Journal of Applied Psychoanalytic Studies, 3(1), 39-50. doi:10.1002/aps.51

*Yip, T., \& Fuligni, A. J. (2002). Daily variation in ethnic identity, ethnic behaviors, and psychological well-being among American adolescents of Chinese descent. Child Development, 73(5), 1557-1572. doi:10.1111/1467-8624.00490

*Yip, T., \& Cross, W. E., Jr. (2004). A daily diary study of mental health and community involvement outcomes for three Chinese American social identities. Cultural Diversity and Ethnic Minority Psychology, 10(4), 394-408. doi:10.1037/1099-9809.10.4.394 
*Yip, T. (2005). Sources of situational variation in ethnic identity and psychological well-being: A palm pilot study of Chinese American students. Personality and Social Psychology Bulletin, 31(12), 1603-1616. doi:10.1177/0146167205277094

*Yip, T., Seaton, E. K., \& Sellers, R. M. (2006). African American racial identity across the lifespan: Identity status, identity content, and depressive symptoms. Child Development, 77(5), 1504-1517. doi:10.1111/j.1467-8624.2006.00950.x

*Yip, T., Gee, G. C., \& Takeuchi, D. T. (2008). Racial discrimination and psychological distress: The impact of ethnic identity and age among immigrant and United States-born Asian adults. Developmental Psychology, 44(3), 787-800. doi:10.1037/00121649.44.3.787

Yoo, H.C., \& Lee, R. M. (2008). Does ethnic identity buffer or exacerbate the effects of frequent racial discrimination on situational well-being of Asian Americans? Journal of Counseling Psychology, 55(1), 63-74. doi:10.1037/0022-0167.55.1.63.

*Yoo, H. C., \& Lee, R. M. (2005). Ethnic identity and approach-type coping as moderators of the racial discrimination/well-being relation in Asian Americans. Journal of Counseling Psychology, 52(4), 497-506. doi:10.1037/0022-0167.52.4.497

*Yoo, H. C. (2006). Racism and well-being of Asian Americans: The role of ethnic identity, approach-type coping, and perceived control. Unpublished doctoral dissertation, University of Minnesota, Minneapolis, MN.

*Yoon, D. P. (1997). Psychological adjustment of Korean-born adolescents adopted by American families. Unpublished doctoral dissertation, Univeristy of Illinois at UrbanaChampaign, Urbana, IL. 
*Yoon, D. P. (2001). Causal modeling predicting psychological adjustment of Korean-born adolescent adoptees. Journal of Human Behavior in the Social Environment, 3(3/4), 6582. doi:10.1300/J137v03n03_06.

*Yuh, J. (2005). Ethnic identity and its relation to self-esteem and ego identity among college students in a multiethnic region. Journal of Applied Social Psychology, 35(6), 1111-1131. doi:10.1111/j.1559-1816.2005.tb02162.x

*Zaff, J. F., Blount, R. L., Phillips, L., \& Cohen, L. (2002). The role of ethnic identity and selfconstrual in coping among African American and Caucasian American seventh graders: An exploratory analysis of within-group variance. Adolescence, 37(148), 751-773. 
Table 1

Descriptions of the 184 Studies Included in the Meta-Analysis.

\begin{tabular}{|c|c|c|c|c|}
\hline Study & $N$ & $\begin{array}{l}\text { Effect } \\
\text { Size }(r)\end{array}$ & $\begin{array}{r}95 \% \\
\text { Lower }\end{array}$ & $\begin{array}{l}\text { CI } \\
\text { Upper }\end{array}$ \\
\hline Adams (1997) & 73 & .31 & .09 & .50 \\
\hline Adelabu (2008) & 661 & .39 & .32 & .45 \\
\hline Ali (2006) & 300 & .24 & .13 & .35 \\
\hline Asner (1999) & 86 & .01 & -.20 & .22 \\
\hline Bacho (1997) & 120 & -.10 & -.26 & .09 \\
\hline Barry (2000) & 150 & -.10 & -.22 & .10 \\
\hline Basurto (1995) & 99 & .17 & -.03 & .36 \\
\hline Beiser \& Hour (2006) & 647 & .02 & -.06 & .10 \\
\hline Bhadha (2001) & 360 & .07 & -.03 & .17 \\
\hline Bhargava (2007) & 147 & -.03 & -.19 & .13 \\
\hline Biggs (1998) & 213 & .24 & .11 & .36 \\
\hline Blash \& Unger (1995) & 68 & .20 & -.04 & .42 \\
\hline Bosarge (2007) & 105 & -.10 & -.24 & .14 \\
\hline Bracey, Bamaca, \& Umana-Taylor (2004) & 1531 & .21 & .16 & .26 \\
\hline Bruner (2004) & 281 & .33 & .22 & .43 \\
\hline Byers (2005) & 197 & .17 & .03 & .31 \\
\hline Canabal (1995) & 101 & .24 & .05 & .42 \\
\hline Carlson, Uppal, \& Prosser (2000) & 685 & .31 & .24 & .38 \\
\hline Carter, Sbrocco, Lewis, \& Friedman (2001) & 59 & .20 & -.06 & .43 \\
\hline
\end{tabular}


Table 1 (continued)

(continued)

Study

Carter et al. (2005)

Chang (1999)

Chapell (1999)

Charlot-Swilley (1997)

Chatman (2006)

Chow (2003)

Christensen (1999)

Cislo (2008)

Creagh-Kaiser (2003)

Daniels (2004)

Dejud (2007)

Delva (2005)

Des Jardins (1996)

Diwan, Jonnalagadda, \& Balaswamy (2004)

Dixon (2002)

Do (2006)

Douglas (2004)

Edwards (2003)

Elek-Fisk (1998)

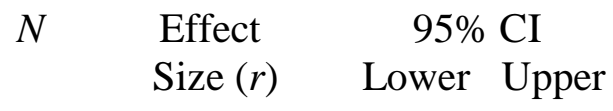

191

.13

$-.01$

.27

120

.37

.20

.52

314

.39

$.29 \quad .48$

99

.45

.28

.60

172

.33

.18

.45

178

.21

.07

.35

96

$-.10$

$-.28$

.60

291

.12

.00

.23

86

.27

.06

.45

88

$-.13$

$-.33 \quad .08$

131

.20

$.03 \quad .36$

75

.13

$-.10$

.35

62

.20

$-.05$

.43

226

$-.01$

$\begin{array}{ll}-.14 & .12\end{array}$

176

.15

$.00 \quad .29$

262

.34

.22

.44

111

$-.02$

$-.21$

.16

293

.13

.01

.24

258

.21

.09

.32

(continued) 
Table 1 (continued)

Study
$N \quad$ Effect $\quad 95 \%$ CI
Size $(r) \quad$ Lower Upper

Eng (1982)

Farver, Narang, \& Bhada (2002)

Foster (2004)

French (2002)

Gamst et al. (2002)

Gamst et al. (2006)

Gaudet, Clement, \& Deuzeman (2005)

Gaylord-Harden, Ragsdale, Mandara, Richards, \& Peterson (2007)

Gilmore (2000)

Gloria \& Hird (1999)

Gong (2007)

Gonzalez (2003)

Goodstein \& Ponterotto (1997)

Gotowiec (1999)

Graham (2001)

Greene (1997)

Harrison (1997)

Hazen (1994)

Holmes (2007)

\begin{tabular}{|c|c|c|c|}
\hline 138 & .16 & .00 & .32 \\
\hline 180 & .05 & -.10 & .19 \\
\hline 142 & .13 & -.04 & .29 \\
\hline 558 & .14 & .05 & .22 \\
\hline 204 & .13 & -.01 & .26 \\
\hline 355 & .09 & -.01 & .20 \\
\hline 96 & .28 & .08 & .45 \\
\hline 227 & .17 & .04 & .29 \\
\hline 49 & .20 & -.09 & .46 \\
\hline 98 & .26 & .06 & .44 \\
\hline 206 & .53 & .42 & .62 \\
\hline 141 & .22 & .06 & .37 \\
\hline 126 & .37 & .21 & .51 \\
\hline 162 & .31 & .16 & .44 \\
\hline 54 & .19 & -.08 & .44 \\
\hline 189 & -.08 & -.22 & .06 \\
\hline 53 & .28 & .01 & .51 \\
\hline 80 & .10 & -.13 & .31 \\
\hline 157 & .03 & -.13 & .19 \\
\hline
\end{tabular}


Table 1 (continued)

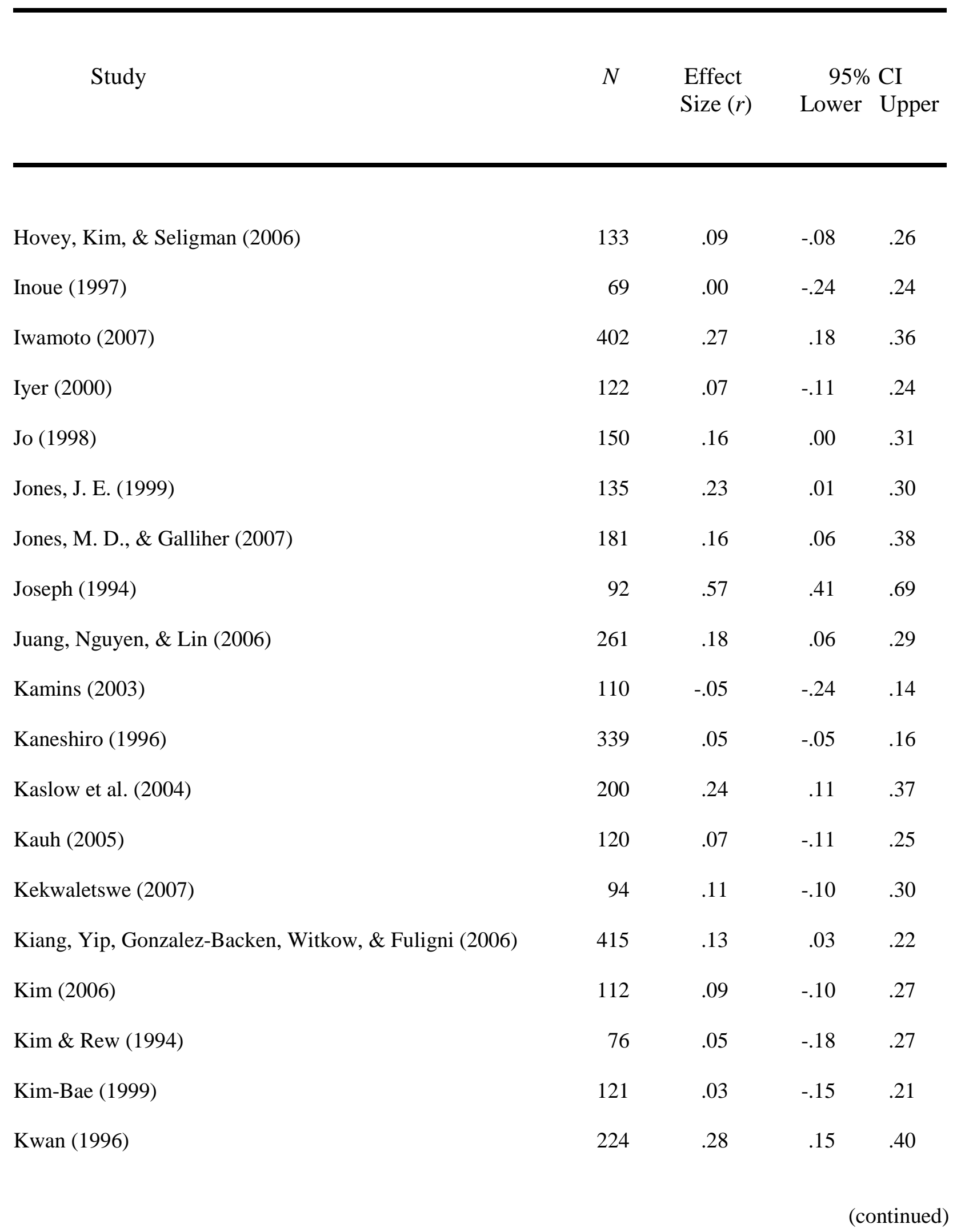


Table 1 (continued)

\begin{tabular}{|c|c|c|c|c|}
\hline Study & $N$ & $\begin{array}{c}\text { Effect } \\
\text { Size }(r)\end{array}$ & $\begin{array}{r}95 \% \\
\text { Lower }\end{array}$ & $\begin{array}{l}\text { CI } \\
\text { Upper }\end{array}$ \\
\hline Lamborn \& Nguyen (2004) & 158 & .23 & .08 & .37 \\
\hline Larson (1995) & 7 & .45 & -.46 & .90 \\
\hline Laurent (1997) & 193 & .41 & .28 & .52 \\
\hline Lavish (2007) & 151 & .19 & .03 & .34 \\
\hline Lee, R. M. (2005) & 84 & .36 & .21 & .44 \\
\hline Lee, R. M. \& Yoo (2004) & 323 & .23 & .12 & .33 \\
\hline Lee, S. (2001) & 217 & .33 & .16 & .53 \\
\hline Lewis, C. (1997) & 85 & .24 & .03 & .43 \\
\hline Lewis, D. (1998) & 100 & -.04 & -.24 & .16 \\
\hline Lopez (2005) & 73 & .41 & .20 & .58 \\
\hline Lorenzo-Hernandez \& Ouellette (1998) & 206 & .46 & .34 & .56 \\
\hline McCubbin (2003) & 243 & .19 & .06 & .30 \\
\hline McDuffie (1997) & 188 & .28 & .14 & .41 \\
\hline McKnight (2003) & 105 & .11 & -.08 & .30 \\
\hline McMahon \& Watts (2002) & 117 & .22 & .04 & .39 \\
\hline Mohanty, Keokse, \& Sales (2006) & 78 & .33 & .12 & .51 \\
\hline Mukoyama (1998) & 86 & .36 & .16 & .53 \\
\hline Nagara (2005) & 253 & .02 & -.10 & .14 \\
\hline Negy, Shreve, Jensen, \& Uddin (2003) & 124 & .17 & -.01 & .34 \\
\hline
\end{tabular}


Table 1 (continued)

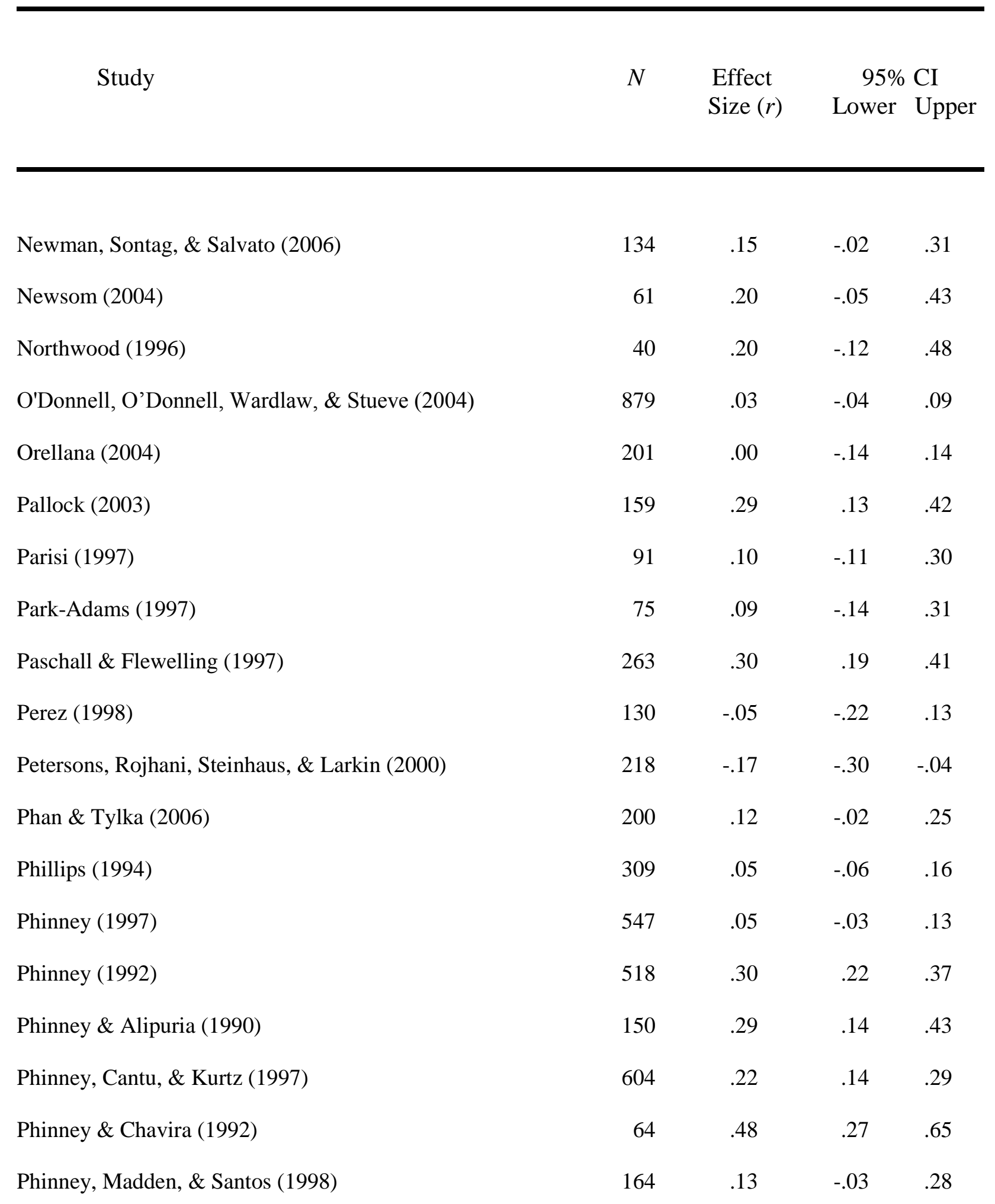

(continued) 
Table 1 (continued)

\begin{tabular}{|c|c|c|c|c|}
\hline Study & $N$ & $\begin{array}{l}\text { Effect } \\
\text { Size }(r)\end{array}$ & $\begin{array}{r}95 \% \\
\text { Lower }\end{array}$ & $\begin{array}{l}\text { CI } \\
\text { Upper }\end{array}$ \\
\hline Pittenger (1998) & 136 & .23 & .07 & .39 \\
\hline Prelow, Bowman, \& Weaver (2007) & 112 & .17 & -.02 & .34 \\
\hline Pugh-Lilly (2000) & 121 & -.07 & -.24 & .11 \\
\hline Quinones (1996) & 147 & .16 & .00 & .31 \\
\hline Ramirez (1997) & 150 & .29 & .14 & .43 \\
\hline Reddy (2002) & 132 & .06 & -.11 & .23 \\
\hline Resnicow, Soler, Braithwaite, Selassie, \& Smith (1999) & 346 & .10 & -.01 & .20 \\
\hline Rivas-Drake, Hughes, \& Way (2008) & 84 & .25 & .03 & .44 \\
\hline Roberts, D. (1997) & 150 & .29 & .09 & .36 \\
\hline Roberts, R. E., et al. (1999) & 1992 & .12 & .08 & .16 \\
\hline Romero \& Roberts (2003) & 881 & .26 & .20 & .32 \\
\hline Rosario (1999) & 80 & .25 & .03 & .45 \\
\hline Rosen (2004) & 71 & -.18 & -.39 & .06 \\
\hline Ryu (2004) & 25 & .53 & .17 & .77 \\
\hline Saavedra (1994) & 212 & .10 & -.04 & .23 \\
\hline Santana (1994) & 204 & .29 & .16 & .41 \\
\hline Sasson (2001) & 21 & .12 & -.33 & .52 \\
\hline Schmidt (2006) & 121 & .16 & -.02 & .33 \\
\hline Schneider (1995) & 94 & .14 & -.06 & .33 \\
\hline
\end{tabular}


Table 1 (continued)

Study

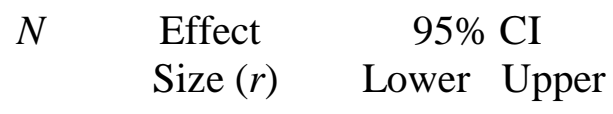

Schwartz, Zamboanga, \& Jarvis (2007)

$\begin{array}{rrrr}347 & .14 & .04 & .24 \\ 65 & -.08 & -.32 & .17 \\ 136 & .08 & -.09 & .25\end{array}$

Shibazaki (1999)

$\begin{array}{llll}136 & .08 & -.09 & .25\end{array}$

Shrake \& Rhee (2004)

$\begin{array}{lllll}217 & .18 & .05 & .31\end{array}$

Siegel, Yancey, \& McCarthy (2000)

$\begin{array}{llll}370 & .12 & .01 & .22\end{array}$

Sieger \& Renk (2007)

$\begin{array}{lllll}134 & .25 & .08 & .40\end{array}$

Smith \& Brookins (1997)

159

Smith, E. P. (2003)

$\begin{array}{rrrr}60 & .21 & -.05 & .44 \\ 126 & .08 & -.09 & .25\end{array}$

Smith, F. D. (2006)

$\begin{array}{lllll}126 & .08 & -.09 & .25\end{array}$

Sobansky (2003)

58

Susberry (2004)

94

Swenson \& Prelow (2005)

133

Tatman (1996)

139

Terrell (2005)

$\begin{array}{llll}115 & .21 & .03 & .38\end{array}$

To (1999)

$\begin{array}{llll}106 & .32 & .14 & .48\end{array}$

Tovar-Murray (2004)

$\begin{array}{llll}196 & .31 & .18 & .43\end{array}$

Tremayne (1997)

$\begin{array}{lllll}30 & .09 & -.28 & .44\end{array}$

Tsoi-Pullar (1994)

209

.34

$.21 \quad .45$

Turnage (1998)

105

.31

$.13 \quad .47$

(continued) 
Table 1 (continued)

Study

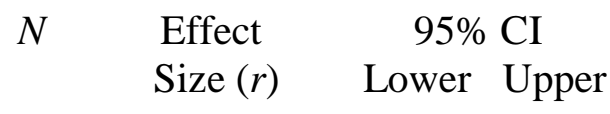

Turnage (2004)

105

Umaña-Taylor (2004)

1061

.36

$.18 \quad .52$

Umaña-Taylor \& Shin (2007)

657

Umaña-Taylor \& Updegraff (2007)

273

Umaña-Taylor, Vargas-Chanes, Garcia, \& Gonzales-Backen

323 (2008)

Umaña-Taylor, Yazedjian, \& Bamaca-Gomez (2004)

468

Utsey, Chae, Brown, \& Kelly (2002)

160

Van Buren (2004)

$$
523
$$

Vuong (2004)

$\begin{array}{llll}109 & -.16 & -.34 & .03\end{array}$

Walker (2002)

$\begin{array}{llll}112 & .17 & -.02 & .34\end{array}$

Walker, Wingate, Obasi, \& Joiner (2008)

$$
296
$$

.19

08

30

Wallen (2001)

$$
145
$$

.09

08

.24

Ware (2006)

$$
200
$$

Weathersby (2007)

$$
316
$$

Webb-Msemaji (1996)

$\begin{array}{llll}112 & .12 & -.07 & .30\end{array}$

West (2004)

$\begin{array}{llll}86 & .07 & -.14 & .28\end{array}$

White \& Burke (1987)

73

.23

$.00 \quad .44$

Wong, Eccles, \& Sameroff (2003)

629

227

.15

.07

.23

Worrell (2007)

$\begin{array}{lll}.21 & .08 \quad .33\end{array}$

(continued) 
Table 1 (continued)

\begin{tabular}{|c|c|c|c|c|}
\hline Study & $N$ & $\begin{array}{l}\text { Effect } \\
\text { Size }(r)\end{array}$ & $\begin{array}{r}95 \% \\
\text { Lower }\end{array}$ & $\begin{array}{l}\text { CI } \\
\text { Upper }\end{array}$ \\
\hline Yang (2006) & 137 & .12 & -.05 & .28 \\
\hline Yasui, Dorham, \& Dishion (2004) & 82 & .49 & .30 & .64 \\
\hline Ying \& Lee (2006) & 197 & .22 & .08 & .35 \\
\hline Yip (2005) & 62 & .01 & -.24 & .26 \\
\hline Yip \& Cross (2004) & 96 & .15 & -.05 & .34 \\
\hline Yip \& Fuligni (2002) & 96 & .15 & -.05 & .34 \\
\hline Yip, Gee, \& Takeuchi (2008) & 2047 & .16 & .11 & .20 \\
\hline Yip, Seaton, \& Sellers (2006) & 940 & .06 & .00 & .12 \\
\hline Yoo (2006) & 249 & .16 & .08 & .39 \\
\hline Yoo \& Lee (2005) & 147 & .24 & .04 & .28 \\
\hline Yoon (2001) & 241 & .15 & .02 & .27 \\
\hline Yuh (2005) & 209 & .30 & .17 & .42 \\
\hline Zaff, Blount, Phillips, \& Cohen (2002) & 67 & .08 & -.16 & .32 \\
\hline
\end{tabular}


Table 2

Differences across Study and Participant Characteristics.

\begin{tabular}{|c|c|c|c|c|c|}
\hline Variable & $Q$ & $p$ & $r$ & $95 \% \mathrm{CI}$ & $k$ \\
\hline Population Sampled & 3.5 & .17 & & & \\
\hline Normal Community Members & & & .14 & {$[.10, .18]$} & 48 \\
\hline Students & & & .18 & {$[.16, .21]$} & 121 \\
\hline At-risk Groups & & & .17 & {$[.11, .24]$} & 15 \\
\hline Race & 4.5 & .21 & & & \\
\hline African American & & & .19 & {$[.15, .23]$} & 48 \\
\hline Asian American & & & .14 & {$[.11, .18]$} & 51 \\
\hline Hispanic/Latino(a) American & & & .13 & {$[.08, .18]$} & 27 \\
\hline Native American & & & .16 & {$[.07, .26]$} & 8 \\
\hline Years of Education & 0.6 & .74 & & & \\
\hline $8^{\text {th }}$ Grade or Less & & & .17 & {$[.11, .22]$} & 20 \\
\hline $9^{\text {th }}$ through $12^{\text {th }}$ Grade & & & .18 & {$[.14, .22]$} & 44 \\
\hline High School Graduate or Greater & & & .19 & {$[.15, .23]$} & 41 \\
\hline Socioeconomic Status & 1.6 & .46 & & & \\
\hline Lower & & & .13 & {$[.08, .19]$} & 23 \\
\hline Lower-Middle & & & .18 & {$[.12, .23]$} & 25 \\
\hline Middle or above & & & .18 & {$[.14, .21]$} & 59 \\
\hline (Table continues) & & & & & \\
\hline
\end{tabular}




\begin{tabular}{lllllll}
\hline Variable & $Q$ & $p$ & $r$ & $95 \% \mathrm{CI}$ & $k$
\end{tabular}

Acculturation Level

$10.8 \quad .01$

Low

$.02[-.09, .13] \quad 5$

Moderate

$.14[.09, .19] \quad 26$

High

$.18 \quad[.14, .23] \quad 35$

No Information Provided

$.18 \quad[.16, .21] \quad 118$

Design-type

$3.9 \quad .05$

Cross-sectional

$.18 \quad[.16, .20] \quad 172$

Longitudinal

$.11[.04, .18] \quad 12$

Publication Status

$3.09 \quad .05$

Unpublished

$\begin{array}{lll}.16 & {[.13, .18]} & 108\end{array}$

Published

$.19 \quad[.17, .22] \quad 76$

Ethnic Identity Measure ${ }^{a}$

$1.0 \quad .62$

MEIM

Other Researched Measure

Other Measure (Homemade)

Collapsed Dependent Measures

Mental Health Symptoms ${ }^{b}$

Self-esteem

Well-being

Multiple ( $>1$ of above)
$.18 \quad[.16, .20] \quad 128$

$.16 \quad[.12, .21] \quad 30$

$.16 \quad[.11, .21] \quad 24$

$48.8<.001$

$.04 \quad[-.01, .10] \quad 17$

$.23 \quad[.20, .26] \quad 59$

$.24[.17, .31] \quad 11$

$.15 \quad[.13, .17] \quad 97$

(Table continues) 


Variable $\quad Q \quad$ p $\quad r \quad 95 \%$ CI $\quad k$

Disaggregated Dependent Measures $^{c} 232.9<.001$

$\begin{array}{llll}\text { Anxiety/distress }^{\mathrm{b}} & .06 & {[.04, .08]} & 33 \\ \text { Depression/hopelessness }^{\mathrm{b}} & .10 & {[.08, .12]} & 51 \\ \text { Other Mental Health Symptoms }^{\mathrm{b}} & .08 & {[.05, .11]} & 35 \\ \text { Behavior Problems }^{\mathrm{b}} & .12 & {[.09, .16]} & 11 \\ \text { General Well-being } & .19 & {[.16, .21]} & 32 \\ \text { Self-esteem } & .21 & {[.20, .22]} & 117 \\ \text { Self-mastery } & .19 & {[.17, .21]} & 35 \\ \text { Social Support } & .14 & {[.12, .16]} & 26 \\ \text { Multiple (>1 of above) } & .12 & {[.06, .19]} & 7\end{array}$

Note. $k=$ number of studies. $\mathrm{a}=$ Two studies that used both the MEIM and another measure of ethnic identity were excluded from this analysis because of shared method variance. $b=$ Scaling was inversed, such that positive correlations denote less pathology. $\mathrm{c}=$ This analysis disaggregated differed types of measures within studies, such that many studies with multiple measurement types had more than one effect size included in the analysis. All other analyses used only one effect size per study. 
Table 3

Random Effects Regression Weights for Study Characteristics Associated with Effect Sizes

\begin{tabular}{lcccc}
\hline \multicolumn{1}{l}{ Variable } & B & SE & $p$ & $\beta$ \\
\hline Constant & .172 & .009 & $<.0001$ & .00 \\
& & & & \\
Participants' Average Age & -.002 & .001 & .03 & -.15 \\
Participant Acculturation Level ${ }^{\mathrm{a}}$ & & & & \\
$\quad$ Low & -.107 & .055 & .05 & -.14 \\
$\quad$ Medium & -.006 & .026 & .82 & -.02 \\
$\quad$ High & .007 & .023 & .76 & .02 \\
Longitudinal Design & -.014 & .039 & .72 & -.03 \\
Measures of Well-being & & & & \\
$\quad$ Mental Health Symptoms & -.093 & .030 & .002 & -.22 \\
$\quad$ Self-esteem & .075 & .019 & .0001 & .27 \\
Global Well-being & .081 & .037 & .03 & .15 \\
& & & & \\
\hline
\end{tabular}

Note. $\mathrm{a}=$ Contrasted with studies not reporting information on participant acculturation level. $\mathrm{b}=$ Contrasted with multi-dimensional measures of well-being. 